PENERAPAN KOMBINASI METODE SAW DAN TOPSIS

DALAM ANALISIS FUNDAMENTAL SAHAM

BERDASARKAN RASIO KEUANGAN

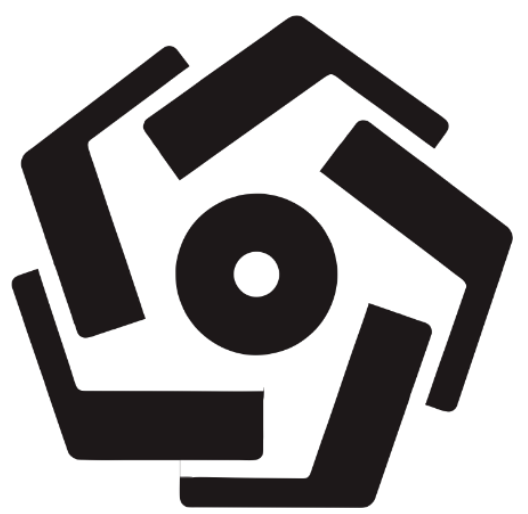

Disusun oleh:

Nama : Angger Binuko Paksi

NIM : 14.52.0538

Konsentrasi : CIO Management

PROGRAM STUDI S2 TEKNIK INFORMATIKA

PROGRAM PASCASARJANA STMIK AMIKOM YOGYAKARTA

YOGYAKARTA

2017 


\section{HALAMAN PENGESAHAN}

PENERAPAN KOMBINASI METODE SAW DAN TOPSIS

DALAM ANALISIS FUNDAMENTAL SAHAM

BERDASARKAN RASIO KEUANGAN

\section{IMPLEMENTATION OF COMBINATION SAW AND TOPSIS METHOD IN STOCK FUNDAMENTAL ANALYSIS \\ BASED IN FINANCIAL RATIOS}

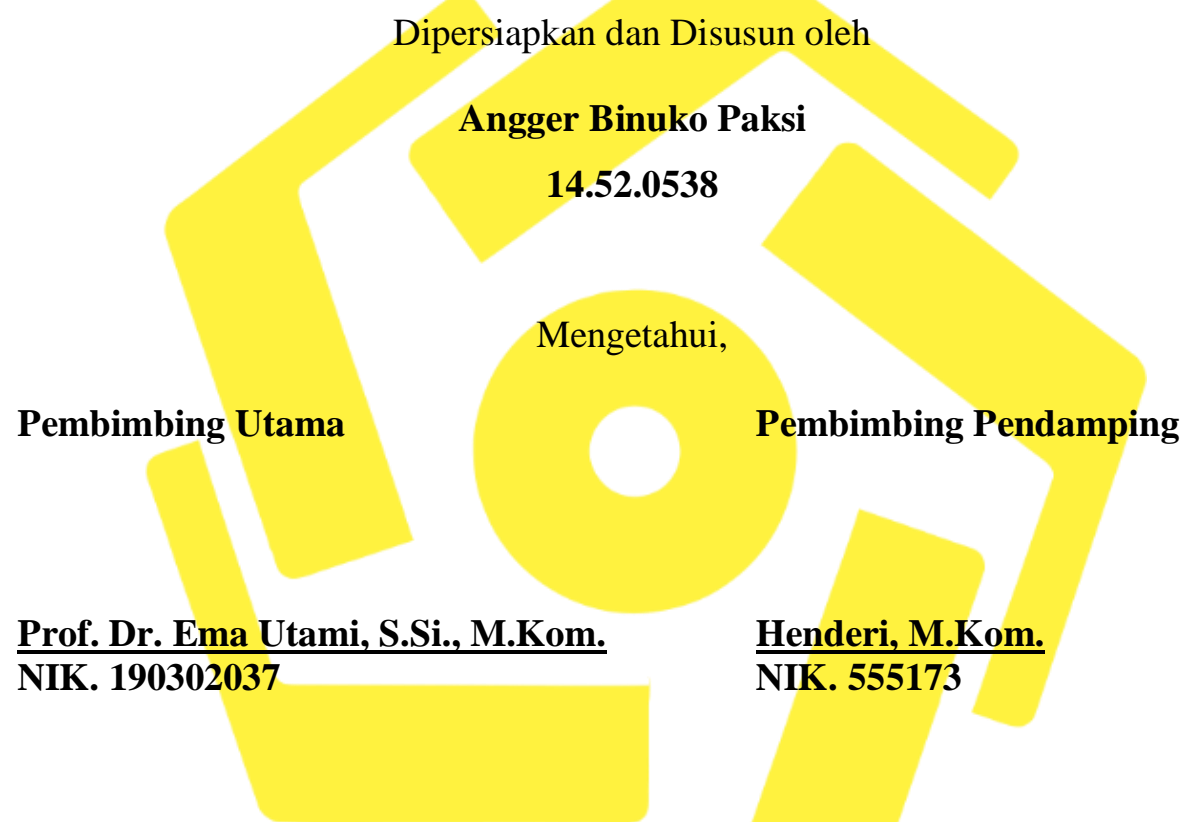

Tesis ini telah diterima sebagai salah satu persyaratan untuk memperoleh gelar Magister Komputer

Yogyakarta, 02 Januari 2017

Direktur Program Pascasarjana

Dr. Kusrini, M.Kom.

NIK. 190302106 


\title{
PENERAPAN KOMBINASI METODE SAW DAN TOPSIS DALAM ANALISIS FUNDAMENTAL SAHAM BERDASARKAN RASIO KEUANGAN
}

\begin{abstract}
Angger Binuko Paksi
Intisari

Investasi saham merupakan satu dari sekian banyak pilihan berinvestasi. Dalam berinvestasi saham dibutuhkan suatu analisis dan tindakan yang tepat agar seorang investor dapat berinvestasi sesuai kebutuhannya. Salah satu caranya dengan analisis fundamental. Analisis fundamental merupakan metode analisis yang menitikberatkan pada data-data kunci yang ada dalam laporan keuangan suatu perusahaan untuk menilai kinerja keuangan perusahaan.

Penelitian ini bertujuan untuk merancang proses analisis fundamental saham berdasarkan analisis rasio keuangan, metode SAW dan metode TOPSIS. Analisis rasio keuangan secara umum meliputi rasio likuiditas, rasio solvabilitas, rasio aktivitas, rasio profitabilitas dan rasio pasar. Bilangan fuzzy digunakan dalam metode SAW dan TOPSIS untuk memberikan efektivitas dalam menentukan nilai matriks keputusan. Metode SAW digunakan untuk mencari nilai matriks ternormalisasi untuk setiap kriteria dan metode TOPSIS digunakan untuk mencari solusi/alternatif berdasarkan nilai matriks ternormalisasi. Kemudian rancangan diterapkan dalam bentuk sistem pemeringkatan berbasis aplikasi web.

Pengujian dilakukan dengan 60 data laporan keuangan dalam periode 2013-2015 yang terbagi dalam 20 emiten. Dari hasil pengujian akurasi menggunakan korelasi pemeringkatan Spearman berdasarkan model Springate didapatkan hasil terendah $85.45 \%$ dan terbesar $100 \%$.
\end{abstract}

Kata kunci: Analisis Fundamental Saham, SAW, TOPSIS, Springate, Spearman.

\begin{abstract}
Investment in stocks is one of the many options to invest. In stock investing requires a proper analysis and action so that an investor can invest according to their needs. One way is fundamental analysis. Fundamental analysis is an analysis method that focuses on key data contained in the financial statements of a company to assess the financial performance of the company.
\end{abstract}

This research aims to design a process of fundamental analysis of stocks based on the analysis of financial ratios, methods of SAW and TOPSIS methods. Analysis of financial ratios generally include the liquidity ratio, solvency, activity ratios, profitability ratios and the ratio of the market. Fuzzy numbers used in the method of SAW and TOPSIS to provide effectiveness in determining the value of the decision matrix. SAW method used to find the value of the normalized matrix for each criterion and TOPSIS methods used to find solutions / alternatives based on the normalized matrix. Then the design is applied in the form of a ranking system based web application.

Tests conducted with 60 financial reports in the period from 2013 to 2015 and is divided into 20 issuers. The accuracy of the test results using Spearman correlation ranking based on Springate models obtained the lowest value of $85.45 \%$ and the largest $100 \%$.

Keywords: Fundamental Analysis of Stocks, SAW, TOPSIS, Springate, Spearman. 


\section{Latar Belakang}

Investasi merupakan suatu langkah seseorang dalam pemenuhan kebutuhan di masa yang akan datang. Investasi saham merupakan satu dari sekian banyak pilihan investasi yang semakin diminati oleh berbagai kalangan. Sosialisasi serta akses yang semakin mudah, menjadi sarana bagi siapa saja untuk bisa ikut serta dalam berinvestasi saham. Teratur, aman dan efisien menjadikan saham sebagai investasi yang menarik setelah deposito, obligasi, properti, dan emas. Setidaknya, dilihat dari volume transaksi perdagangan yang terus meningkat dari waktu ke waktu. Hampir semua negara saat ini memiliki bursa saham, dengan pengkodean indeks saham masing-masing. Misalnya beberapa bursa saham yang cukup awam terdengar di telinga, indeks Nikkei dari Jepang, indeks Hang Seng dari Hongkong, indeks Kospi dari Korea ataupun indeks Dow Jones dari Amerika. Di Indonesia sendiri ada bursa saham yang dikenal dengan BEI (Bursa Efek Indonesia) atau dikenal dengan nama IDX (Indonesia Stock Exchange) di pasar saham Internasional. BEI sendiri memiliki beberapa indeks saham di antaranya IHSG (Indeks Harga Saham Gabungan), LQ 45, JII (Jakarta Islamic Index), dsb. Intinya, bursa saham mencerminkan kemajuan perekonomian dari suatu negara.Berdasarkan data BEI pada tanggal 07 September 2016, telah tercatat 536 emiten yang terbagi dalam 10 sektor industri yaitu sektor Pertanian, Pertambangan, Industri Dasar, Aneka Industri, Barang Konsumsi, Properti, Infrastruktur, Keuangan, Perdagangan dan Jasa, dan Manufaktur. Diantara sektor-sektor tersebut berdasarkan hasil analisis yang dilakukan Prihatmo Hari Mulyanto (2016) selaku Direktur Utama PT Danareksa Investment, sektor Barang Konsumsi diprediksi akan mendominasi pertumbuhan kinerja IHSG di tahun 2016, ini dikarenakan kebutuhan konsumsi rumah tangga berdasarkan produk domestik bruto (PDB) terus meningkat. Sektor Keuangan dan sektor Properti juga diprediksi menjadi penunjang pertumbuhan kinerja IHSG, dikarenakan adanya beberapa kebijakan pemerintah yang mampu menunjang pertumbuhan 2 sektor tersebut, diantaranya keputusan menurunkan BI rate dan perubahan ketentuan LTV (Loan to Value Ratio) dan FTV (Financing to Value Ratio) dimana hal ini akan mempermudah kredit atau pembiayaan properti.

Prediksi pergerakan suatu saham dapat dilakukan dengan dua cara, yaitu dengan menggunakan analisis fundamental dan analisis teknikal. Analisis fundamental merupakan metode analisis yang menggunakan studi tentang keadaan ekonomi, industri, dan kondisi perusahaan untuk menentukan nilai wajar dari harga saham perusahaan (Hendy, 2008). Sedangkan analisis teknikal merupakan sebuah metode yang paling dasar dalam investasi di pasar modal dengan mengamati grafik pergerakan harga dan volume saham. Salah satu teknik analisis fundamental yang umum digunakan adalah analisis rasio keuangan. Analisis rasio keuangan ini didasarkan pada fundamental ekonomi suatu perusahaan, yang secara teknis akan menitik beratkan pada rasio keuangan di dalam laporan keuangan perusahaan. Sebagian pakar berpendapat analisis fundamental lebih cocok untuk membuat keputusan dalam memilih saham perusahaan mana yang dibeli untuk jangka panjang. Analisis rasio keuangan saat ini masih banyak dilakukan dengan perhitungan manual, sehingga akan memakan cukup banyak waktu untuk melakukan perhitungan dan pemilihan saham yang layak untuk dijadikan pilihan berinvestasi, namun adanya sebuah sistem pemeringkatan yang dapat mengolah data-data dari analisis rasio keuangan akan membantu para investor dalam proses pemilihan berinvestasi saham lebih efektif dan efisien.

Menurut Kuswadi (2006) dalam buku Memahami Rasio-rasio Keuangan bagi Orang Awam, seorang analis dapat menggunakan analisis rasio sebanyak-banyaknya bergantung kebutuhan, namun biasanya analisis rasio keuangan digolongkan menjadi Rasio Likuiditas, Rasio Solvabilitas, Rasio Aktivitas dan Rasio Profitabilitas. Rasio itu harus dibandingkan dengan rata-rata industri. Menurut Hery (2015) dalam buku Analisis Laporan Keuangan 
Pendekatan Rasio Keuangan untuk menilai kinerja perusahaan maka sejumlah rasio keuangan haruslah digunakan secara bersama-sama, namun jika satu aspek yang ingin dinilai maka pengukuran atau penggunaan satu atau dua rasio keuangan dianggap sudah mencukupi. Perbandingan kinerja antar perusahaan seharusnya dilakukan dengan menggunakan data keuangan dari perusahaan sejenis dan pada periode waktu yang sama.

Menurut Henry Wibowo (2010) dalam penelitian berjudul MADM-Tool : Aplikasi Uji Sensitivitas untuk Model MADM Menggunakan Metode SAW dan TOPSIS, kedua metode tersebut memiliki konsep sederhana, mudah dipahami, komputasinya efisien dan memiliki kemampuan untuk mengukur kinerja relatif dari alternatif-alternatif keputusan dalam bentuk matematis yang sederhana. Metode SAW digunakan untuk mencari nilai matriks ternormalisasi R untuk setiap kriteria. Sedangkan metode TOPSIS digunakan untuk mencari solusi atau alternatif berdasarkan hasil nilai matriks ternormalisasi dari metode SAW. Berdasarkan pustaka dan penelitian di atas, dengan penerapan metode SAW dan TOPSIS dalam membuat seleksi peringkat untuk memberikan rekomendasi saham berdasarkan analisis rasio keuangan, diharapkan dapat membantu para investor dalam menentukan pilihan berinvestasi saham yang menguntungkan tanpa harus membuang banyak waktu dan tenaga untuk melakukan analisis fundamental secara konvensional atau perhitungan manual. Dan berdasarkan penelitian Yan Satria Setyawan, et al. (2015) pengujian pada penelitian ini akan menggunakan metode analisis rasio keuangan sebagai pembanding dari metode yang digunakan pada penelitian ini. Dimana metode yang dapat digunakan sebagai pembanding adalah metode Springate, kemudian pengukuran akurasi akan menggunakan koefisien korelasi pemeringkatan Spearman.

\section{Rumusan Masalah}

Dari latar belakang yang telah disampaikan maka dapat dirumuskan masalah-masalah dalam penelitian ini di antaranya:

1. Seperti apa rancangan proses analisis fundamental saham berdasarkan analisis rasio keuangan, metode SAW dan metode TOPSIS?

2. Apakah penerapan metode SAW dan TOPSIS untuk mengolah hasil perhitungan analisis rasio keuangan dapat menghasilkan rekomendasi alternatif saham?

\section{Batasan Variabel Penelitian}

Adapun batasan-batasan variabel dalam penelitian ini agar fokus tujuan penelitian ini dapat tercapai adalah sebagai berikut:

1. Data saham yang akan diteliti adalah saham yang terdaftar pada papan utama BEI dari 2 sektor industri berpengaruh berdasarkan olah data BEI, yaitu:

a. Sektor Barang Konsumsi meliputi 10 saham dengan kode AISA, ICBP, INDF, KAEF, KLBF, MYOR, ROTI, SIDO, ULTJ, dan UNVR.

b. Sektor Properti meliputi 10 saham dengan kode ADHI, ASRI, BKSL, BSDE, CTRA, KIJA, LPKR, SMRA, WIKA dan WSKT.

2. Laporan keuangan yang diteliti adalah laporan keuangan tahunan dari saham-saham yang terpilih pada poin (a) dan telah di audit serta dipublikasikan di situs resmi BEI (www.idx.co.id) pada periode 2013 sampai 2015.

3. Teknik analisis fundamental saham yang digunakan adalah analisis rasio keuangan yang terdiri dari:

a. Rasio likuiditas meliputi Current Ratio, Quick Ratio, Cash Ratio.

b. Rasio solvabilitas meliputi Debt to Asset Ratio, Debt to Equity Ratio, Long Term Debt to Equity Ratio, Equity Multiplier. 
c. Rasio aktivitas meliputi Accounts Receivable Turnover, Inventory Turnover, Working Capital Turnover, Fixed Assets Turnover, Total Assets Turnover.

d. Rasio profitabilitas meliputi Return on Assets, Return on Equity, Gross Profit Margin, Operating Profit Margin, Net Profit Margin.

e. Rasio pasar meliputi Price Earnings Ratio, Price to Book Value Ratio.

4. Metode yang digunakan dalam sistem pemeringkatan adalah :

a. Fungsi Keanggotaan Fuzzy - Representasi Linear, digunakan untuk menentukan nilai bobot berdasarkan standard ratio (rata-rata industri).

b. Metode SAW, digunakan untuk mencari nilai matriks ternormalisasi R untuk setiap kriteria.

c. Metode TOPSIS, digunakan untuk mencari solusi/alternatif berdasarkan nilai matriks ternormalisasi yang dihasilkan dari metode SAW.

5. Data-data saham pada poin (a) akan menjadi alternatif input-an sistem yang akan dibangun pada penelitian ini.

6. Rasio-rasio pada poin (c) akan menjadi kriteria input-an sistem yang akan dibangun pada penelitian ini.

7. Bobot preferensi setiap kriteria (rasio keuangan) ditentukan berdasarkan peraturan menteri BUMN No. KEP-100/MBU/2002 dan PER-10/MBU/2014.

8. Fokus pada penelitian ini adalah penerapan kombinasi metode SAW dan TOPSIS dalam membangun sistem pemeringkatan alternatif saham berdasarkan hasil dari pemrosesan analisis rasio keuangan.

9. Sistem pemeringkatan berupa prototype aplikasi web yang dikembangkan dengan bahasa pemrograman PHP dan basis data MySQL.

10. Hasil akhir dari sistem yang dibangun adalah mampu memberikan rekomendasi alternatif saham dalam bentuk pemeringkatan.

11. Pengujian akurasi berdasarkan scoring model Springate dan koefisien korelasi pemeringkatan Spearman.

\section{Tujuan Penelitian}

Penelitian ini dilakukan dengan tujuan yang dirinci sebagai berikut :

1. Membuat rancangan proses analisis fundamental saham berdasarkan analisis rasio keuangan, metode SAW dan metode TOPSIS.

2. Menerapkan hasil perancangan ke dalam bentuk sistem pemeringkatan pada sebuah modul perangkat lunak.

3. Memperoleh rekomendasi dari alternatif saham yang dapat menunjang dalam pengambilan keputusan berinvestasi saham dengan lebih efektif dan efisien.

4. Sebagai syarat kelulusan Program Magister Teknik Informatika, Pascasarjana STMIK Amikom Yogyakarta.

\section{Manfaat Penelitian}

Adapun manfaat dari penelitian adalah sebagai berikut:

1. Bagi penulis, memperoleh ilmu pengetahuan teori maupun teknis dari bidang ekonomi berupa analisis rasio keuangan dan teknologi informatika berupa perancangan dan pembangunan sistem pemeringkatan saham.

2. Bagi pembaca, penelitian ini dapat dijadikan bahan pendukung maupun acuan untuk mengembangkan penelitian lebih lanjut pada bidang yang berkaitan.

3. Bagi masyarakat umum, aplikasi yang dibuat diharapkan dapat membantu memberikan rekomendasi alternatif dalam pemilihan saham untuk berinvestasi di pasar saham. 


\section{Keaslian Penelitian}

Tabel 1. Matriks Literatur Review dan Posisi Penelitian

Penerapan Sistem Pendukung Keputusan dalam Analisis Fundamental Saham Berdasarkan Rasio Keuangan

\begin{tabular}{|c|c|c|c|c|c|c|}
\hline No & Judul & $\begin{array}{l}\text { Peneliti, Media } \\
\text { Publikasi, dan } \\
\text { Tahun }\end{array}$ & Tujuan Penelitian & Kesimpulan & Saran atau Kelemahan & Perbandingan \\
\hline 1 & $\begin{array}{l}\text { Applying TOPSIS } \\
\text { method to evaluate } \\
\text { the Business } \\
\text { Operation } \\
\text { Performance of } \\
\text { Vietnam Listing } \\
\text { Securities Companies }\end{array}$ & $\begin{array}{l}\text { Tien-Chin } \\
\text { Wang, Jui-Fang } \\
\text { Chang, } \\
\text { Truong Ngoc } \\
\text { Anh, Wan- } \\
\text { Tseng Chang, } \\
\text { IEEE, 2010 }\end{array}$ & $\begin{array}{l}\text { Melakukan analisis } \\
\text { strategis investasi } \\
\text { dengan menggunakan } \\
\text { Inventory Turnover, } \\
\text { Net Income Ratio, } \\
\text { Earnings per Share, } \\
\text { Current Ratio, Return } \\
\text { on total Assets } \\
\text { (ROA), dan Return } \\
\text { on common Equity } \\
\text { (ROE) sebagai } \\
\text { kriteria, metode } \\
\text { entropy untuk } \\
\text { menentukan bobot } \\
\text { masing-masing } \\
\text { kriteria serta TOPSIS } \\
\text { untuk mengukur } \\
\text { indeks kinerja relatif } \\
\text { dan mengurutkannya. }\end{array}$ & $\begin{array}{l}\text { Penggunaan metode } \\
\text { entropy untuk } \\
\text { menghitung bobot } \\
\text { kriteria dan TOPSIS } \\
\text { dapat menghindarkan } \\
\text { pengaruh faktor } \\
\text { subjektif, sehingga } \\
\text { hasil pengurutan lebih } \\
\text { meyakinkan. }\end{array}$ & $\begin{array}{l}\text { Analisis fundamental } \\
\text { pada penelitian masih } \\
\text { terbatas pada } \\
\text { penggunaan rasio-rasio } \\
\text { keuangan, sehingga } \\
\text { untuk pengembangan } \\
\text { masih dapat digunakan } \\
\text { beberapa rasio-rasio } \\
\text { keuangan yang lain } \\
\text { untuk mendapatkan hasil } \\
\text { pemeringkatan yang } \\
\text { lebih baik. }\end{array}$ & $\begin{array}{l}\text { Pada penelitian yang akan } \\
\text { dilakukan membahas lebih } \\
\text { banyak bentuk rasio } \\
\text { keuangan sebagai kriteria } \\
\text { dan menggunakan metode } \\
\text { SAW-TOPSIS dalam } \\
\text { membangun sistem } \\
\text { pendukung keputusan. }\end{array}$ \\
\hline
\end{tabular}


Tabel 1. Matriks Literatur Review dan Posisi Penelitian (lanjutan)

\begin{tabular}{|c|c|c|c|c|c|c|}
\hline No & Judul & $\begin{array}{l}\text { Peneliti, Media } \\
\text { Publikasi, dan } \\
\text { Tahun }\end{array}$ & Tujuan Penelitian & Kesimpulan & Saran atau Kelemahan & Perbandingan \\
\hline 2 & $\begin{array}{l}\text { A Fuzzy Logic System } \\
\text { for Evaluating } \\
\text { Financial Profit } \\
\text { Ratios }\end{array}$ & $\begin{array}{l}\text { Carlos } \\
\text { Cubaque-Zorro, } \\
\text { Juan Carlos } \\
\text { Figueroa- } \\
\text { Garcia, IEEE, } \\
2014\end{array}$ & $\begin{array}{l}\text { Menggunakan fuzzy } \\
\text { logic system (FLS) } \\
\text { untuk mengolah } \\
\text { informasi akuntansi } \\
\text { dan fuzzy yang } \\
\text { disediakan para ahli } \\
\text { tentang rasio } \\
\text { profitabilitas untuk } \\
\text { mendapatkan profit } \\
\text { margin yang sesuai. }\end{array}$ & $\begin{array}{l}\text { Hasil dari FLS } \\
\text { memungkinkan untuk } \\
\text { menggunakan } \\
\text { pengetahuan analis, } \\
\text { dan prosedur ini tidak } \\
\text { hanya untuk } \\
\text { mengevaluasi } \\
\text { keuangan perusahaan, } \\
\text { tetapi memberikan } \\
\text { informasi interval } \\
\text { pertumbuhan profit } \\
\text { margin. }\end{array}$ & $\begin{array}{l}\text { Penelitian hanya fokus } \\
\text { pada penilaian rasio } \\
\text { profitabilitas atau } \\
\text { keuntungan perusahaan, } \\
\text { sehingga hasil yang } \\
\text { disampaikan tidak } \\
\text { mempertimbangkan } \\
\text { nilai risiko-risiko yang } \\
\text { mungkin dihadapi oleh } \\
\text { perusahaan, seperti } \\
\text { hutang dan operasional } \\
\text { misalnya. }\end{array}$ & $\begin{array}{l}\text { Penggunaan rasio likuiditas } \\
\text { dan solvabilitas pada } \\
\text { penelitian yang akan } \\
\text { dilakukan memperkaya } \\
\text { kriteria untuk menilai } \\
\text { kesehatan keuangan } \\
\text { perusahaan, sehingga } \\
\text { penilaian tidak hanya melihat } \\
\text { dari sisi keuntungan yang } \\
\text { dihasilkan perusahaan, } \\
\text { namun juga melihat dari sisi } \\
\text { lain seperti jumlah hutang } \\
\text { dan operasional perusahaan. }\end{array}$ \\
\hline 3 & $\begin{array}{l}\text { Analisis Laporan } \\
\text { Keuangan } \\
\text { Perusahaan Sebagai } \\
\text { Dasar Pengambilan } \\
\text { Keputusan Investasi } \\
\text { Saham Berbasis Du } \\
\text { Pont System \& Fuzzy } \\
\text { Logic }\end{array}$ & $\begin{array}{l}\text { Achmad Zakki } \\
\text { Falani, Jurnal } \\
\text { LINK Vol } \\
\text { 18/No.1 ISSN: } \\
\text { 1858-4667, } \\
2013\end{array}$ & $\begin{array}{l}\text { Memberikan } \\
\text { kemudahan kepada } \\
\text { perusahaan untuk } \\
\text { mengendalikan } \\
\text { laporan keuangannya } \\
\text { serta sebagai salah } \\
\text { satu alat tolak ukur } \\
\text { terhadap investor } \\
\text { yang nantinya ingin } \\
\text { berinvestasi saham. }\end{array}$ & $\begin{array}{l}\text { Implementasi du pont } \\
\text { system dan fuzzy logic } \\
\text { akan didapat sebuah } \\
\text { rekomendasi keputusan } \\
\text { yang tepat dan akurat. } \\
\text { Sistem yang } \\
\text { dikembangkan } \\
\text { mendukung terhadap } \\
10 \text { saham yang } \\
\text { diujikan. }\end{array}$ & $\begin{array}{l}\text { Du Pont System hanya } \\
\text { fokus terhadap nilai } \\
\text { ROE meskipun di dalam } \\
\text { perhitungannya } \\
\text { mencakup nilai dari } \\
\text { faktor-faktor lain, hal ini } \\
\text { membuat } d u \text { pont system } \\
\text { kurang efektif untuk } \\
\text { mengadakan } \\
\text { perbandingan antara dua } \\
\text { permasalahan atau lebih. }\end{array}$ & $\begin{array}{l}\text { Fokus penelitian yang akan } \\
\text { dilakukan adalah } \\
\text { memaparkan hasil } \\
\text { pemeringkatan beberapa } \\
\text { saham sejenis dengan } \\
\text { membandingkan setiap hasil } \\
\text { dari analisis rasio likuiditas, } \\
\text { solvabilitas, aktivitas, } \\
\text { profitabilitas dan pasar } \\
\text { dengan metode SAW- } \\
\text { TOPSIS. }\end{array}$ \\
\hline
\end{tabular}


Tabel 1. Matriks Literatur Review dan Posisi Penelitian (lanjutan)

\begin{tabular}{|c|c|c|c|c|c|c|}
\hline No & Judul & $\begin{array}{l}\text { Peneliti, Media } \\
\text { Publikasi, dan } \\
\text { Tahun }\end{array}$ & Tujuan Penelitian & Kesimpulan & Saran atau Kelemahan & Perbandingan \\
\hline 4 & $\begin{array}{l}\text { Implementasi Metode } \\
\text { Fuzzy Analytical } \\
\text { Hierarchy Process } \\
\text { (F-AHP) Sebagai } \\
\text { Pendukung } \\
\text { Keputusan Investasi } \\
\text { Pada Perusahaan } \\
\text { Berdasarkan Rasio } \\
\text { Keuangan (Studi } \\
\text { Pada Perusahaan } \\
\text { Farmasi Yang } \\
\text { Terdaftar di BEI } \\
\text { Periode 2013) }\end{array}$ & $\begin{array}{l}\text { Yan Satria } \\
\text { Setyawan, } \\
\text { Wayan Firdaus } \\
\text { Mahmudy, } \\
\text { Indriati, Jurnal } \\
\text { PTIIK } \\
\text { Universitas } \\
\text { Brawijaya, } \\
2015\end{array}$ & $\begin{array}{l}\text { Mengimplementasika } \\
\mathrm{n} \text { metode Fuzzy AHP } \\
\text { sebagai pendukung } \\
\text { keputusan investasi } \\
\text { pada } \\
\text { perusahaanberdasarka } \\
\text { n rasio keuangan. }\end{array}$ & $\begin{array}{l}\text { Penggunaan F-AHP } \\
\text { dalam SPK dapat } \\
\text { dilakukan dengan cara } \\
\text { menghitung nilai rasio } \\
\text { keuangan sebgai } \\
\text { kriteri. Hasil Penelitian } \\
\text { berjalan sesuai } \\
\text { kebutuhan fungsional } \\
\text { dengan pengujian black } \\
\text { box yang memberikan } \\
\text { hasil dengan presentasi } \\
\text { sebesar } 100 \% \text {. }\end{array}$ & $\begin{array}{l}\text { Penambahan sumber } \\
\text { informasi, Kombinasi } \\
\text { antara F-AHP dengan } \\
\text { metode SPK lainnya, } \\
\text { Sistem dapat } \\
\text { dikembangan untuk } \\
\text { dapat lebih dinamis } \\
\text { dimana dapat } \\
\text { ditambahkan fitur-fitur } \\
\text { seperti fasilitas } \\
\text { pendaftaran anggota } \\
\text { sistem atau pengelolaan } \\
\text { inputan matriks. }\end{array}$ & $\begin{array}{l}\text { Penelitian terkait } \\
\text { menggunakan metode F- } \\
\text { AHP dan dikembangkan } \\
\text { berbasis desktop dengna } \\
\text { menggunakan bahasa } \\
\text { pemrogram Java. } \\
\text { Sedangkan penelitian ini } \\
\text { menggunakan metode SPK } \\
\text { SAW-TOPSIS aplikasi } \\
\text { dikembangkan berbasis Web } \\
\text { dengan bahasa pemrograman } \\
\text { utama PHP. }\end{array}$ \\
\hline 5 & $\begin{array}{l}\text { Sistem Pendukung } \\
\text { Keputusan Pemilihan } \\
\text { Saham Berbabasis } \\
\text { Web Dengan } \\
\text { Pemodelan AHP } \\
\text { (Analytic Hierarchy } \\
\text { Process) Dan } \\
\text { Analsisi Rasio } \\
\text { Keuangan }\end{array}$ & $\begin{array}{l}\text { Rajim } \\
\text { Laymond S, } \\
\text { Tesis S2 Ilmu } \\
\text { Komputer } \\
\text { UGM, } 2013\end{array}$ & $\begin{array}{l}\text { Membangun sistem } \\
\text { pendukung keputusan } \\
\text { pemilihan saham } \\
\text { berbasis web dengan } \\
\text { pemodelan Analytical } \\
\text { Hierarchy Process } \\
\text { (AHP) dan analisis } \\
\text { rasio. }\end{array}$ & $\begin{array}{l}\text { Prioritas saham } \\
\text { ditentukan dengan } \\
\text { perkalian prioritas rasio } \\
\text { dengan rata-rata } \\
\text { pertumbuhan rasio } 5 \\
\text { tahun. Laporan hasil } \\
\text { akhir adalah peringkat } \\
\text { saham tertinggi hingga } \\
\text { terendah, hasil akhir } \\
\text { akan selalu berbeda } \\
\text { berdasarkan preferensi } \\
\text { pengguna. }\end{array}$ & $\begin{array}{l}\text { Penelitian dapat } \\
\text { dikembangkan dalam } \\
\text { beberapa metode sistem } \\
\text { pendukung keputusan. } \\
\text { Analisis rasio yang } \\
\text { digunakan masih } \\
\text { terbatas pada ROE dan } \\
\text { ROA. }\end{array}$ & $\begin{array}{l}\text { Penelitian yang akan } \\
\text { dilakukan menggunakan } \\
\text { analisis rasio keuangan yang } \\
\text { lebih variatif meliputi rasio } \\
\text { likuiditas, rasio leverage, } \\
\text { rasio aktivity, rasio } \\
\text { profitabilitas, rasio pasar dan } \\
\text { juga metode SAW-TOPSIS } \\
\text { untuk sistem pendukung } \\
\text { keputusan. }\end{array}$ \\
\hline
\end{tabular}


Tabel 1. Matriks Literatur Review dan Posisi Penelitian (lanjutan)

\begin{tabular}{|c|c|c|c|c|c|c|}
\hline No & Judul & $\begin{array}{l}\text { Peneliti, Media } \\
\text { Publikasi, dan } \\
\text { Tahun }\end{array}$ & Tujuan Penelitian & Kesimpulan & Saran atau Kelemahan & Perbandingan \\
\hline 6 & $\begin{array}{l}\text { Sistem Pendukung } \\
\text { Keputusan Kelompok } \\
\text { Dalam Pemilihan } \\
\text { Saham Menggunakan } \\
\text { Metode AHP, } \\
\text { Promethee dan Borda }\end{array}$ & $\begin{array}{l}\text { Muslimin. B, } \\
\text { Tesis, S2 Ilmu } \\
\text { Komputer } \\
\text { UGM, } 2016\end{array}$ & $\begin{array}{l}\text { Membangun suatu } \\
\text { sistem pendukung } \\
\text { keputusan kelompok } \\
\text { dalam pemilihan } \\
\text { saham dengan } \\
\text { menggunakan metode } \\
\text { AHP, PROMETHEE } \\
\text { dan Borda, yang } \\
\text { dapat menampung } \\
\text { hasil analisa } \\
\text { preferensi masing- } \\
\text { masing pengambil } \\
\text { keputusan. }\end{array}$ & $\begin{array}{l}\text { Hasil sistem } \\
\text { pendukung keputusan } \\
\text { kelompok dalam } \\
\text { pemilihan saham } \\
\text { menggunakan metode } \\
\text { AHP, PROMETHEE } \\
\text { dan Borda dapat } \\
\text { dijadikan sebagai } \\
\text { rekomendasi bagi } \\
\text { investor dalam } \\
\text { pemilihan saham yang } \\
\text { optimal. Implementasi } \\
\text { sistem pendukung } \\
\text { keputusan kelompok } \\
\text { dalam pemilihan saham } \\
\text { dapat melakukan } \\
\text { perubahan data kriteria } \\
\text { dan alternatif, sehingga } \\
\text { evaluasi perkembangan } \\
\text { alternatif saham } \\
\text { perusahaan dapat } \\
\text { ditentukan sesuai } \\
\text { kebutuhan. }\end{array}$ & $\begin{array}{l}\text { Penelitian } \\
\text { membandingkan saham- } \\
\text { saham yang berbeda } \\
\text { sector, meskipun hal ini } \\
\text { bisa dilakukan hasil } \\
\text { yang disampaikan tidak } \\
\text { dijamin validitasnya } \\
\text { karena analisis saham } \\
\text { yang baik adalah } \\
\text { membandingkan saham- } \\
\text { saham yang } \\
\text { sejeni/dalam sector yang } \\
\text { sama. Penelitian ini juga } \\
\text { dapat dikembangkan ke } \\
\text { versi web base. }\end{array}$ & $\begin{array}{l}\text { Penelitian yang akan } \\
\text { dilakukan menggunakan } \\
\text { metode SAW-TOPSIS } \\
\text { dengan data saham yang } \\
\text { akan digunakan digolongkan } \\
\text { tiap sektor industri, sehingga } \\
\text { meminimalkan resiko } \\
\text { perbedaan data dan istilah } \\
\text { dalam pengumpulan data, } \\
\text { serta membuat proses } \\
\text { komputasi lebih efisien. }\end{array}$ \\
\hline
\end{tabular}




\section{Metode Penelitian}

Metode penelitian yang digunakan adalah Forward Engineering Research. Menurut Ade Djohar Maturidi (2012), Forward Engineering Research merupakan bagian dari Research and Development dimana penelitian bertujuan untuk mengembangkan/merekayasa suatu produk/sistem agar memiliki kualitas yang lebih tinggi. Adapun tahapan yang dilakukan dalam Forward Engineering Research adalah sebagai berikut:

1. Perencanaan (Planning)

2. Perancangan (Design)

3. Pembangunan (Construct)

4. Penerapan (Applied/Implementation)

\section{Metode Pengumpulan Data}

Berdasarkan jenis datanya, data-data yang dikumpulkan adalah sebagai berikut:

1. Data Primer, didapat dengan metode observasi dengan melakukan penganalisaan terhadap objek atau bahan yang diteliti, pengamatan ini dilakukan dengan mengumpulkan data-data laporan keuangan perusahaan yang terdaftar dalam Bursa Efek Indonesia.

2. Data Sekunder, yakni mencari referensi teori atau data-data dokumentasi yang relevan dengan penelitian yang akan dilakukan.

\section{Metode Analisis Data}

1. Metode analisis laporan keuangan menggunakan analisis rasio terdiri dari :

a. Rasio Likuiditas, rasio ini digunakan untuk mengukur kemampuan perusahaan memenuhi kewajiban finansial jangka pendek. Rasio likuiditas dapat dihitung berdasarkan informasi modal kerja dari pos-pos aktiva lancar dan hutang lancar.

b. Rasio Solvabilitas, rasio ini digunakan untuk mengukur seberapa jauh aktiva perusahaan dibiayai dengan hutang atau dibiayai oleh pihak luar.

c. Rasio Aktivitas, rasio untuk mengukur seberapa efektif perusahaan dalam memanfaatkan sumber daya yang dimiliki.

d. Rasio Profitabilitas atau Rasio Keuntungan digunakan untuk mengukur seberapa besar kemampuan perusahaan memperoleh laba dalam hubungan dengan penjualan, aktiva maupun laba dan modal sendiri.

e. Rasio Pasar, rasio ini digunakan untuk mengestimasi nilai intrinsik perusahaan (nilai saham).

2. Metode sistem pemeringkatan akan menggunakan:

a. Fungsi Keanggotaan Fuzzy - Representasi Linear, pemetaan input ke derajat keanggotaan pada representasi linear digambarkan dengan suatu garis lurus. (Edy Irwansyah dan Muhammad Faisal, 2015).

b. Metode SAW (Simple Additive Weighting) yang sering juga dikenal dengan istilah metode penjumlahan terbobot. Konsep dasar metode SAW adalah mencari penjumlahan terbobot dari rating kinerja pada setiap alternatif pada semua atribut (Nofriansyah, 2014).

c. Metode TOPSIS (Technique for Order Preference by Similarity to Ideal Solution) merupakan salah satu metode pengambilan keputusan multi kriteria yang pertama kali diperkenalkan oleh (Yoon dan Hwang, 1981). Konsep dari TOPSIS dikenal sederhana dan mudah dipahami, komputasinya efisien, dan memiliki kemampuan mengukur kinerja relatif dari alternatif-alternatif keputusan dalam bentuk matematis yang sederhana (Kusumadewi, 2006). 
3. Metode pengujian akurasi sistem pemeringkatan akan menggunakan:

a. Model Springate, model ini dikembangkan pada tahun 1978 di S.F.U. oleh Gordon L.V. Springate, mengikuti prosedur yang dikembangkan oleh Altman di Amerika. Springate menggunakan langkah analisis diskriminasi ganda untuk memilih empat dari 19 rasio keuangan populer yang terbaik dibedakan antara bisnis yang sehat dan yang benar-benar gagal. (Frank Vickers, 2006).

b. Rank Correlation (Spearman), koefisien korelasi Spearman digunakan untuk mengetahui derajat keeratan dua variabel yang memiliki skala pengukuran minimal ordinal. Pada perhitungan Spearman, data peringkatnya yang dikorelasikan. (Dergibson Siagiaan, Sugiarto, 2006).

\section{Alur Penelitian}

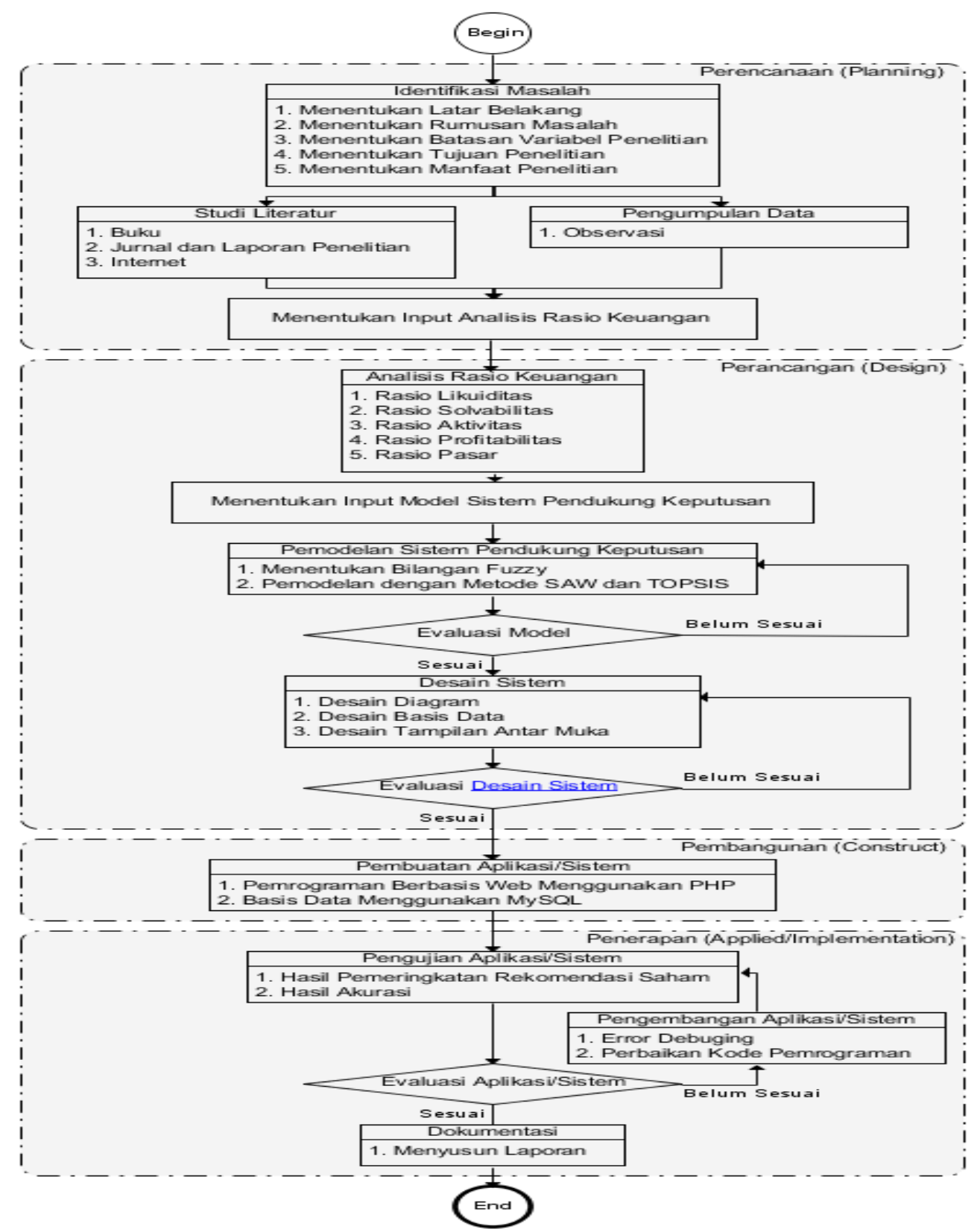

Gambar 1. Alur Penelitian 


\section{Tinjauan Pustaka}

Adapun penelitian yang memiliki keterkaitan baik secara langsung maupun tidak langsung dengan permasalahan pemilihan saham yang telah dilakukan oleh beberapa peneliti sebelumnya untuk mendukung penelitian ini di antaranya:

Penelitian Tien-Chin Wang, et al. (2010) yang dipublikasikan oleh IEEE melalui International Conference on Computational Aspects of Social Networks dengan judul "Applying TOPSIS method to evaluate the Business Operation Performance of Vietnam Listing Securities Companies" bertujuan membantu melakukan analisis strategis investasi dengan menggunakan Inventory Turnover, Net Income Ratio, Earnings per Share, Current Ratio, Return on total Assets (ROA), dan Return on common Equity (ROE) sebagai kriteria, metode entropy untuk menentukan bobot masing-masing kriteria serta TOPSIS untuk mengukur indeks kinerja relatif dan mengurutkannya.

Penelitian Carlos Cubaque-Zorro dan Figueroa-Garcia (2014) yang dipublikasikan oleh IEEE melalui Conference on Norbert Wiener in the 21 st Century $(21 \mathrm{CW})$ dengan judul " $A$ Fuzzy Logic System for Evaluating Financial Profit Ratios" bertujuan untuk mengolah informasi akuntansi dan fuzzy yang disediakan para ahli tentang rasio profitabilitas untuk mendapatkan profit margin yang sesuai dengan menggunakan fuzzy logic system (FLS).

Penelitian Achmad Zakki Falani (2013) yang dipublikasikan pada jurnal LINK, Volume 18, No.1, Maret 2013 yang berjudul "Analisis Laporan Keuangan Perusahaan Sebagai Dasar Pengambilan Keputusan Investasi Saham Berbasis Du Pont System \& Fuzzy Logic” bertujuan untuk memberikan kemudahan kepada perusahaan untuk mengendalikan laporan keuangannya serta sebagai salah satu alat tolak ukur terhadap investor yang nantinya ingin berinvestasi saham, dengan metode $d u$ pont system untuk mengukur tingkat kesehatan finansial perusahaan melalui ROE (Return on Equity), dimana hasil dari nilai ROE akan diolah dengan fuzzy logic untuk menghasilkan rekomendasi keputusan.

Penelitian Yan Satria Setyawan, et al. (2015) yang dipublikasikan pada jurnal PTIIK Universitas Brawijaya, volume 5, no.10 yang berjudul "Implementasi Metode Fuzzy Analytical Hierarchy Process (F-AHP) Sebagai Pendukung Keputusan Investasi Pada Perusahaan Berdasarkan Rasio Keuangan (Studi Pada Perusahaan Farmasi Yang Terdaftar Di BEI Periode 2013)" bertujuan untuk menerapkan metode Fuzzy Analytical Hierarchy Process (F-AHP) sebagai pendukung keputusan investasi pada perusahaan berdasarkan rasio keuangan. Studi kasus yang mereka gunakan adalah perusahaan farmasi yang terdaftar di BEI pada periode 2013. Sistem yang mereka kembangkan berbasis desktop dengan bahasa pemrogram Java. Hasil pengujian validasi adalah $100 \%$ yang menunjukkan fungsionalitas sistem dapat berjalan sesuai dengan daftar kebutuhan. Hasil pengujian akurasi menggunakan koefisien korelasi pemeringkatan Spearman dan didapat hasil tertinggi yaitu sebesar 0.9833 .

Penelitian Rajim Laymond S (2013) berupa Tesis S2 Ilmu Komputer Universitas Gadjah Mada yang berjudul "Sistem Pendukung Keputusan Pemilihan Saham Berbasis Web Dengan Pemodelan Analytical Hierarchy Process (AHP) Dan Analisis Rasio Keuangan” bertujuan untuk membangun sistem pendukung keputusan pemilihan saham dengan pemodelan AHP yang mendukung perbandingan banyak rasio. Prioritas saham ditentukan dengan perkalian prioritas rasio dengan rata-rata pertumbuhan rasio 5 tahun. Laporan hasil akhir adalah peringkat saham tertinggi hingga terendah, hasil akhir akan selalu berbeda berdasarkan preferensi pengguna dan tidak akan ada saham yang menempati peringkat sama. 
Penelitian Muslimin. B (2016) berupa Tesis S2 Ilmu Komputer Universitas Gadjah Mada yang berjudul "Sistem Pendukung Keputusan Kelompok Dalam Pemilihan Saham Menggunakan Metode AHP, Promethee dan Borda" bertujuan untuk merancang dan membangun suatu sistem pendukung keputusan kelompok yang dapat menampung hasil analisis preferensi masing-masing pengambil keputusan dimana hasilnya dapat dijadikan acuan bagi investor dalam berinvestasi saham. Penelitian melakukan dua pendekatan ekonomi, analisis fundamental dan analisis teknikal dimana Net Profit Margin (NPM), Return on Assets (ROA), Return on Equity (ROE), Earning Per Share (EPS) dan Price Earning Ratio (PER) sebagai kriteria analisis fundamental, serta penggunaan tren saham perusahaan (price moves in trend), saham perusahaan yang selalu berulang (history repeat itself) dan refleksi semua kejadian (market price discounts everything) sebagai kriteria analisis teknikal.

\section{Landasan Teori}

1. Analisis Fundamental Saham

Dalam analisis fundamental, analis menganalisis faktor-faktor ekonomi yang mempengaruhi perusahaan dalam upaya untuk memprediksi perkembangan perusahaan di masa yang akan datang. Analisis laporan keuangan dan analisis rasio termasuk komponen yang digunakan pada analisis fundamental (Hin, 2008).

2. Laporan Keuangan

Laporan yang dikeluarkan oleh emiten merupakan salah atau pedoman penting bagi investor untuk menilai kondisi emiten tersebut. Oleh karena itu perusahaan yang telah tercatat di BEI, wajib mengumumkan laporan keuangannya secara periodik. Aspekaspek umum laporan keuangan perusahaan terbagi menjadi dua, yaitu (Hin, 2008):

a. Neraca, dibagi menjadi dua kolom, kolom kiri untuk aktif sedangkan kolom kanan untuk kewajiban dan modal. Sehingga total jumlah kolom kiri akan selalu sama dengan total jumlah kolom kanan.

b. Laporan Laba/Rugi, ringkasan pendapatan dan biaya suatu perusahaan untuk periode tertentu, misalnya tiga bulan atau satu tahun.

3. Analisis Laporan Keuangan

Menurut Leopold A. Bernstein (2000) via (Arifin, 2007) memberikan pengertian bahwa analisis laporan keuangan mencakup penerapan metode dan teknis analisis atau laporan keuangan dan data lainnya untuk melihat dari laporan itu ukuran-ukuran dan hubungan tertentu yang sangat berguna dalam proses pengambilan keputusan.

Analisis laporan keuangan suatu perusahaan dilakukan dengan beberapa tujuan di antaranya (Arifin, 2007):

a. Screening dalam memilih alternatif investasi atau merger.

b. Forecasting atau meramalkan kondisi keuangan perusahaan di masa mendatang.

c. Mendiagnosis adanya masalah-masalah yang terjadi baik dalam manajemen, operasi, keuangan dan masalah lain.

d. Sebagai alat evaluasi kinerja manajemen, operasi, efisiensi, dsb.

Beberapa teknik analisis laporan keuangan yang umum digunakan di antaranya (Arifin, 2007):
a. Analisis Perbandingan
c. Analisis Common Size
b. Analisis Index dan Trend
d. Analisis Rasio Keuangan

4. Analisis Rasio Keuangan

Analisis rasio keuangan merupakan alat untuk mengevaluasi kinerja perusahaan berdasarkan data-data yang ada pada laporan keuangan. Analisis ini dilakukan dengan menggabungkan berbagai perkiraan yang ada pada laporan keuangan dalam bentuk rasio keuangan. 
Terdapat 5 kelompol rasio keuangan yang sering digunakan untuk menilai kondisi keuangan dan kinerja perusahaan seperti terlihat pada Tabel 2 (Hery, 2015):

Tabel 2. Kelompok rasio keuangan

\begin{tabular}{|c|c|c|c|}
\hline No & Kelompok Rasio & Jenis rasio & Rumus \\
\hline \multirow{6}{*}{1} & \multirow{6}{*}{ Rasio Likuiditas } & \multirow{2}{*}{ Current Ratio } & Aset Lancar \\
\hline & & & $\overline{\text { Kewajiban Jangka Pendek }}$ \\
\hline & & \multirow{2}{*}{ Quick Ratio } & (Aset Lancar - Persediaan) \\
\hline & & & Kewajiban Jangka Pendek \\
\hline & & \multirow{2}{*}{ Cash Ratio } & Kas dan Setara Kas \\
\hline & & & $\overline{\text { Kewajiban Jangka Pendek }}$ \\
\hline \multirow{8}{*}{2} & \multirow{8}{*}{ Rasio Solvabilitas } & \multirow{2}{*}{ Debt to Asset Ratio } & Total Kewajiban \\
\hline & & & Total Aset \\
\hline & & \multirow{2}{*}{ Debt to Equity Ratio } & Total Kewajiban \\
\hline & & & Total Ekuitas \\
\hline & & \multirow{2}{*}{ Long Term Debt to Equity Ratio } & Kewajiban Jangka Panjang \\
\hline & & & Total Ekuitas \\
\hline & & \multirow{2}{*}{ Equity Multiplier } & Total Aset \\
\hline & & & $\overline{\text { Total Ekuitas }}$ \\
\hline \multirow{10}{*}{3} & \multirow{10}{*}{ Rasio Aktivitas } & \multirow{2}{*}{ Accounts Receivable Turnover } & Penjualan Neto \\
\hline & & & $\overline{\text { Rata-rata Piutang }}$ \\
\hline & & \multirow{2}{*}{ Inventory Turnover } & Beban Pokok Penjualan \\
\hline & & & $\overline{\text { Rata-rata Persediaan }}$ \\
\hline & & \multirow{2}{*}{ Working Capital Turnover } & Penjualan Neto \\
\hline & & & $\overline{\text { Rata-rata Aset Lancar }}$ \\
\hline & & \multirow{2}{*}{ Fixed Assets Turnover } & Penjualan Neto \\
\hline & & & $\overline{\text { Rata-rata Aset Tetap }}$ \\
\hline & & \multirow{2}{*}{ Total Assets Turnover } & Penjualan Neto \\
\hline & & & $\overline{\text { Rata-rata Total Aset }}$ \\
\hline \multirow{10}{*}{4} & \multirow{10}{*}{ Rasio Profitabilitas } & \multirow{2}{*}{ Return on Assets } & Laba Bersih \\
\hline & & & Total Aset \\
\hline & & \multirow{2}{*}{ Return on Equity } & Laba Bersih \\
\hline & & & $\overline{\text { Total Ekuitas }}$ \\
\hline & & \multirow{2}{*}{ Gross Profit Margin } & Laba Kotor \\
\hline & & & $\overline{\text { Penjualan Neto }}$ \\
\hline & & \multirow{2}{*}{ Operating Profit Margin } & Laba Usaha \\
\hline & & & $\overline{\text { Penjualan Neto }}$ \\
\hline & & \multirow{2}{*}{ Net Profit Margin } & Laba Bersih \\
\hline & & & $\overline{\text { Penjualan Neto }}$ \\
\hline \multirow{4}{*}{5} & \multirow{4}{*}{ Rasio Pasar } & \multirow{2}{*}{ Price Earnings Ratio } & Harga Saham Per Lembar \\
\hline & & & Laba Per Saham \\
\hline & & & Harga Saham Per Lembar \\
\hline & & Price to Book Value Ratio & $\overline{\left(\frac{\text { Total Ekuitas }}{\text { Jumlah Saham Beredar }}\right)}$ \\
\hline
\end{tabular}


5. Fungsi Keanggotaan Fuzzy - Representasi Linear

Fungsi Keanggotaan merupakan kurva yang memetakan titik-titik input data ke dalam nilai keanggotaannya. Kurva tersebut memiliki interval antara 0-1. Salah satu cara yang dapat digunakan untuk mendapatkan nilai keanggotaan adalah dengan melalui pendekatan fungsi (Edy Irwansyah dan Muhammad Faisal, 2015).

6. SAW (Simple Additive Weighting)

Metode Simple Additive Weighting (SAW) sering juga dikenal dengan istilah metode penjumlahan terbobot. Konsep dasar metode Simple Additive Weighting adalah mencari penjumlahan terbobot dari rating kinerja pada setiap alternatif pada semua atribut. Metode SAW disarankan untuk menyelesaikan masalah penyeleksian dalam sistem pengambilan keputusan multi proses. Metode SAW merupakan metode yang banyak digunakan dalam pengambilan keputusan yang memiliki banyak atribut. Metode SAW membutuhkan proses normalisasi matriks keputusan (X) ke suatu skala yang didapat diperbandingkan dengan skala semua rating alternatif yang ada (Nofriansyah, 2014).

7. TOPSIS (Technique for Order Preference by Similarity to Ideal Solution)

TOPSIS merupakan salah satu metode pengambilan keputusan multi kriteria yang diperkenalkan oleh (Yoon dan Hwang, 1981). Metode ini banyak digunakan untuk menyelesaikan pengambilan keputusan secara praktis. Hal ini disebabkan karena konsep dari TOPSIS sederhana dan mudah dipahami, komputasinya efisien, dan memiliki kemampuan mengukur kinerja relatif dari alternatif-alternatif keputusan dalam bentuk matematis yang sederhana (Kusumadewi, 2006).

8. Model Springate

Model ini dikembangkan pada tahun 1978 di S.F.U. oleh Gordon L.V. Springate, mengikuti prosedur yang dikembangkan oleh Altman di Amerika. Springate menggunakan langkah analisis diskriminasi ganda untuk memilih empat dari 19 rasio keuangan populer yang terbaik dibedakan antara bisnis yang sehat dan yang benarbenar gagal. Springate melakukan tes terhadap 40 perusahaan dan mendapatkan nilai akurasi sebersar $92.5 \%$ (Frank Vickers, 2006).

9. Korelasi Pemeringkatan Spearman

Spearman digunakan untuk mengetahui derajat keeratan dua variabel yang memiliki skala pengukuran minimal ordinal. Pada perhitungan Spearman, data peringkatnya yang akan dikorelasikan. (Dergibson Siagiaan, Sugiarto, 2006).

\section{Gambaran Umum}

Dalam berinvestasi saham dibutuhkan suatu analisis dan tindakan yang tepat agar seorang investor dapat berinvestasi sesuai kebutuhannya. Salah satu caranya dengan analisis fundamental. Analisis fundamental merupakan metode analisis yang menitikberatkan pada data-data kunci yang ada dalam laporan keuangan suatu perusahaan untuk menilai kinerja keuangan perusahaan. Pada penelitian ini akan dilakukan perancangan proses analisis fundamental saham berdasarkan analisis rasio keuangan, kemudian dari hasil analisis rasio keuangan setiap emiten alternatif akan dijadikan variabel metode SAW dan metode TOPSIS untuk menentukan hasil akhir pemeringkatan tingkat kesehatan keuangan masingmasing emiten alternatif. Dan dari hasil perancangan akan diterapkan dalam sistem pemeringkatan berbasis web dengan pemrograman PHP. Data-data yang digunakan dalam penelitian merupakan data laporan keuangan setiap emiten alternatif yang diunduh dari situs resmi Bursa Efek Indonesia (BEI) dengan alamat www.idx.co.id. BEI sendiri adalah pihak yang menyelenggarakan dan menyediakan sistem dan atau sarana untuk mempertemukan penawaran jual dan beli efek pihak - pihak lain dengan tujuan memperdagangkan efek di antara mereka. 
Untuk memahami gambaran umum penelitian dapat dilihat skema pada Gambar 2 berikut:

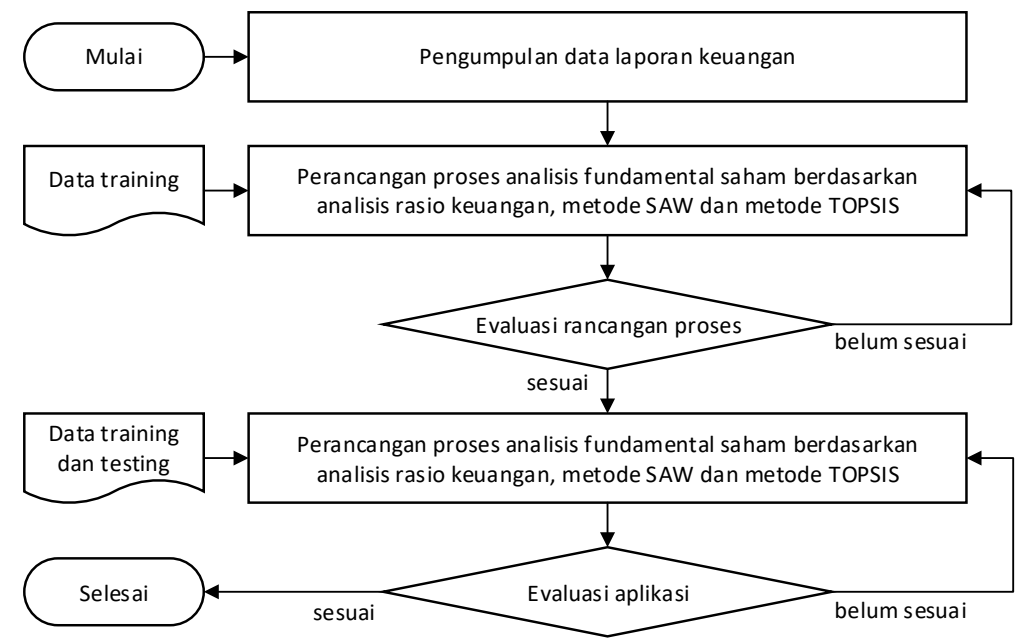

Gambar 2. Skema Gambaran Umum

\section{Analisis dan Rancangan Sistem}

1. Analisis Sistem

a. Analisis Kebutuhan Data

Berdasarkan hasil observasi terhadap analisis yang dilakukan Prihatmo Hari Mulyanto (2016) selaku Direktur Utama PT Danareksa Investment, dalam penelitian ini ditentukan 20 data emiten sebagai alternatif pemilihan saham dimana nantinya setiap emiten akan dilakukan screening untuk mendapatkan data-data kunci yang digunakan untuk proses analisis rasio keuangan. Data-data emiten tersebut di antaranya ditunjukkan pada Tabel 3 berikut:

Tabel 3. Data emiten (data alternatif penelitian)

\begin{tabular}{|c|l|l|l|}
\hline No & $\begin{array}{c}\text { Kode } \\
\text { Saham }\end{array}$ & \multicolumn{1}{|c|}{ Sektor Industri } & \multicolumn{1}{c|}{ Nama Perusahaan } \\
\hline 1 & AISA & Barang Konsumsi & Tiga Pilar Sejahtera Food Tbk. \\
\hline 2 & ICBP & Barang Konsumsi & Indofood CBP Sukses Makmur Tbk. \\
\hline 3 & INDF & Barang Konsumsi & Indofood Sukses Makmur Tbk. \\
\hline 4 & KAEF & Barang Konsumsi & Kimia Farma Tbk. \\
\hline 5 & KLBF & Barang Konsumsi & Kalbe Farma Tbk. \\
\hline 6 & MYOR & Barang Konsumsi & Mayora Indah Tbk. \\
\hline 7 & ROTI & Barang Konsumsi & Nippon Indosari Corpindo Tbk. \\
\hline 8 & SIDO & Barang Konsumsi & Industri Jamu dan Farmasi Sido Muncul Tbk. \\
\hline 9 & ULTJ & Barang Konsumsi & Ultra Jaya Milk Industry \& Trading Co Tbk. \\
\hline 10 & UNVR & Barang Konsumsi & Unilever Indonesia Tbk. \\
\hline 11 & ADHI & Properti & Adhi Karya (Persero) Tbk. \\
\hline 12 & ASRI & Properti & Alam Sutera Realty Tbk. \\
\hline 13 & BKSL & Properti & Sentul City Tbk. \\
\hline 14 & BSDE & Properti & Bumi Serpong Damai Tbk. \\
\hline 15 & CTRA & Properti & Ciputra Development Tbk. \\
\hline 16 & KIJA & Properti & Kawasan Industri Jababeka Tbk. \\
\hline 17 & LPKR & Properti & Lippo Karawaci Tbk. \\
\hline 18 & SMRA & Properti & Summarecon Agung Tbk. \\
\hline 19 & WIKA & Properti & Wijaya Karya (Persero) Tbk. \\
\hline 20 & WSKT & Properti & Waskita Karya (Persero) Tbk. \\
\hline
\end{tabular}


Berdasarkan tabel pemetaan formula analisis rasio keuangan maka dapat ditentukan kriteria dan juga standard ratio setiap kriteria. Nilai standard ratio menurut (Hery, 2015) terangkum dalam Tabel 4 berikut:

Tabel 4. Data jenis rasio (data kriteria penelitian)

\begin{tabular}{|c|l|r|l|}
\hline Kriteria & \multicolumn{1}{|c|}{ Nama Kriteria } & $\begin{array}{c}\text { Standard } \\
\text { Ratio }\end{array}$ & \multicolumn{1}{|c|}{ Keterangan } \\
\hline C1 & Current Ratio & 1.70 & Semakin tinggi semakin baik \\
\hline C2 & Quick Ratio & 1.50 & Semakin tinggi semakin baik \\
\hline C3 & Cash Ratio & 0.50 & Semakin tinggi semakin baik \\
\hline C4 & Debt to Asset Ratio & 0.50 & Semakin rendah semakin baik \\
\hline C5 & Debt to Equity Ratio & 0.50 & Semakin rendah semakin baik \\
\hline C6 & Long Term Debt to Equty Ratio & 0.40 & Semakin rendah semakin baik \\
\hline C7 & Equity Multiplier & 1.00 & Semakin rendah semakin baik \\
\hline C8 & Accounts Receivable Turnover & 25.00 & Semakin tinggi semakin baik \\
\hline C9 & Inventory Turnover & 17.00 & Semakin tinggi semakin baik \\
\hline C10 & Working Capital Turnover & 7.00 & Semakin tinggi semakin baik \\
\hline C11 & Fixed Assets Turnover & 3.00 & Semakin tinggi semakin baik \\
\hline C12 & Total Assets Turnover & 2.00 & Semakin tinggi semakin baik \\
\hline C13 & Return on Assets & 0.20 & Semakin tinggi semakin baik \\
\hline C14 & Return on Equity & 0.30 & Semakin tinggi semakin baik \\
\hline C15 & Gross Profit Margin & 0.28 & Semakin tinggi semakin baik \\
\hline C16 & Operating Profit Margin & 0.23 & Semakin tinggi semakin baik \\
\hline C17 & Net Profit Margin & 0.20 & Semakin tinggi semakin baik \\
\hline C18 & Price Earnings Ratio & 8.00 & Semakin rendah semakin baik \\
\hline C19 & Price to Book Value Ratio & 5.00 & Semakin rendah semakin baik \\
\hline
\end{tabular}

Data-data kunci yang dibutuhkan dalam penelitian terlihat di Tabel 5 berikut:

Tabel 5. Data-data kunci laporan keuangan

\begin{tabular}{|l|l|}
\hline No & Data-data kunci laporan keuangan \\
\hline 1 & Aset Lancar \\
\hline 2 & Kas dan Setara Kas \\
\hline 3 & Piutang \\
\hline 4 & Persediaan \\
\hline 5 & Aset Tetap \\
\hline 6 & Total Aset \\
\hline 7 & Kewajiban Jangka Pendek \\
\hline 8 & Kewajiban Jangka Panjang \\
\hline 9 & Total Kewajiban \\
\hline 10 & Total Ekuitas \\
\hline 11 & Penjualan/Pendapatan Neto \\
\hline 12 & Beban Pokok Penjualan \\
\hline 13 & Laba Kotor \\
\hline 14 & Laba Usaha/Operasional \\
\hline 15 & Laba Bersih \\
\hline 16 & Laba Per Saham (EPS) \\
\hline 17 & Harga Saham Per Lembar (per 30 Desember tahun laporan) \\
\hline 18 & Jumlah Saham Beredar \\
\hline
\end{tabular}

b. Pemodelan Sistem Pemeringkatan

Setelah ditentukan data alternatif, data kriteria, data kunci laporan keuangan, dan juga bobot masing-masing kriteria, maka tahapan selanjutnya dalam analisis 
sistem penelitian ini adalah proses pemodelan sistem pemeringkatan, pada tahapan ini data yang dipaparkan pada laporan tesis hanya sebagian dari keseluruhan data training sebagai contoh proses pemodelan. Skema dalam tahapan pemodelan sistem pemeringkatan menggunakan metode SAW-TOPSIS ini terlihat seperti Gambar 3 berikut:

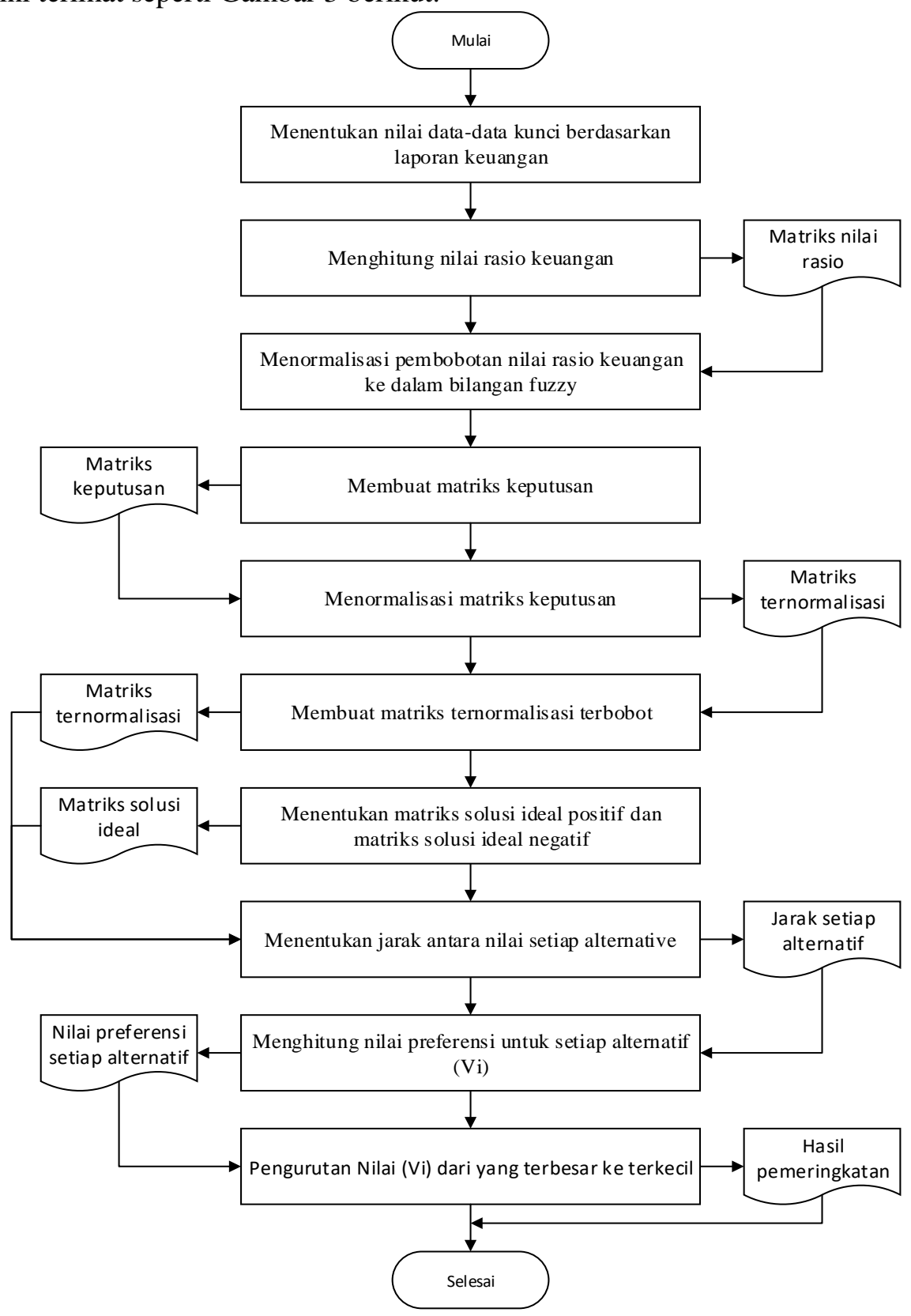

Gambar 3. Skema pemodelan metode SAW-TOPSIS

\section{Perancangan Sistem}

Perancangan sistem merupakan tahap setelah analisis sistem, dimana akan dipaparkan bagaimana proses sistem berjalan. Pada penelitian ini perancangan sistem dimulai dari perancangan UML, kemudian akan dilanjutkan dengan perancangan basis data dan selanjutnya merancangan dialog antar muka. 
a. Rancangan UML

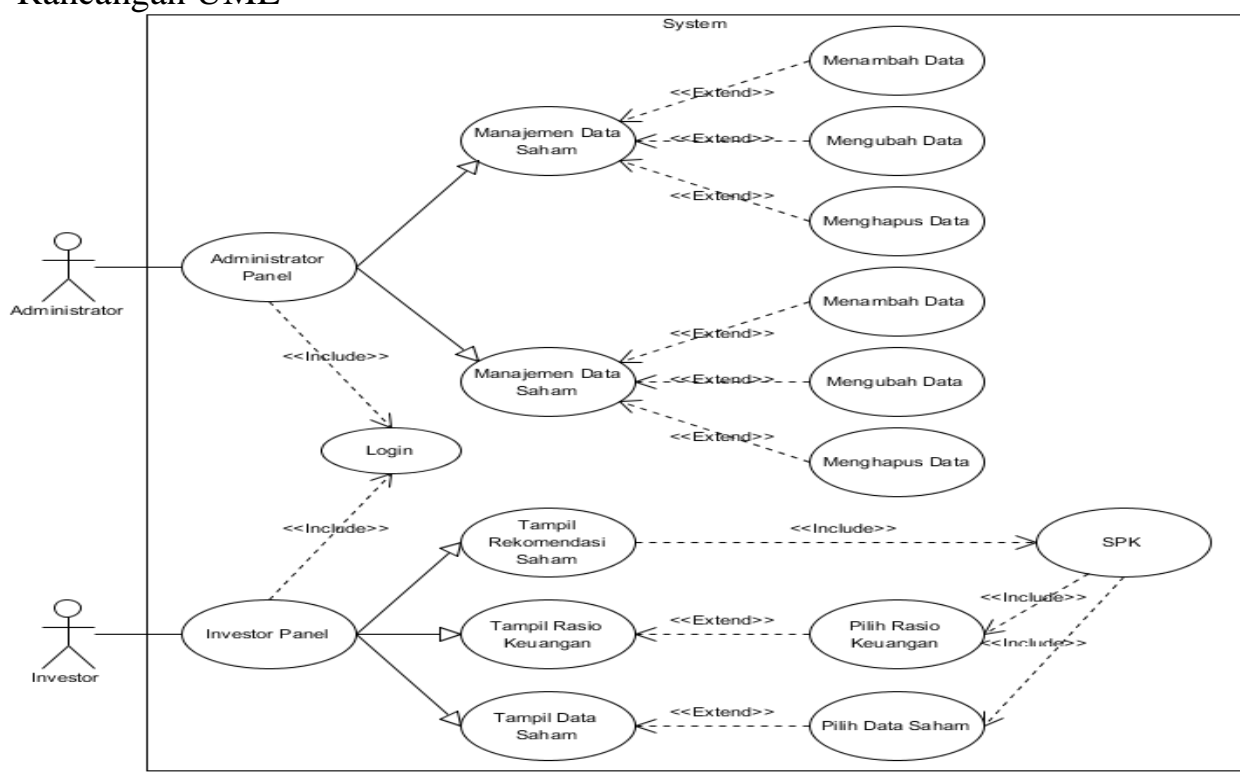

Gambar 4. Use case diagram perancangan sistem

b. Rancangan Basis Data

Untuk mendukung pengembangan sistem maka dibutuhkan basis data untuk menampung kebutuhan informasi yang dibutuhkan dalam sistem. Perancangan basis data yang diterapkan pada sistem terlihat pada Gambar berikut:

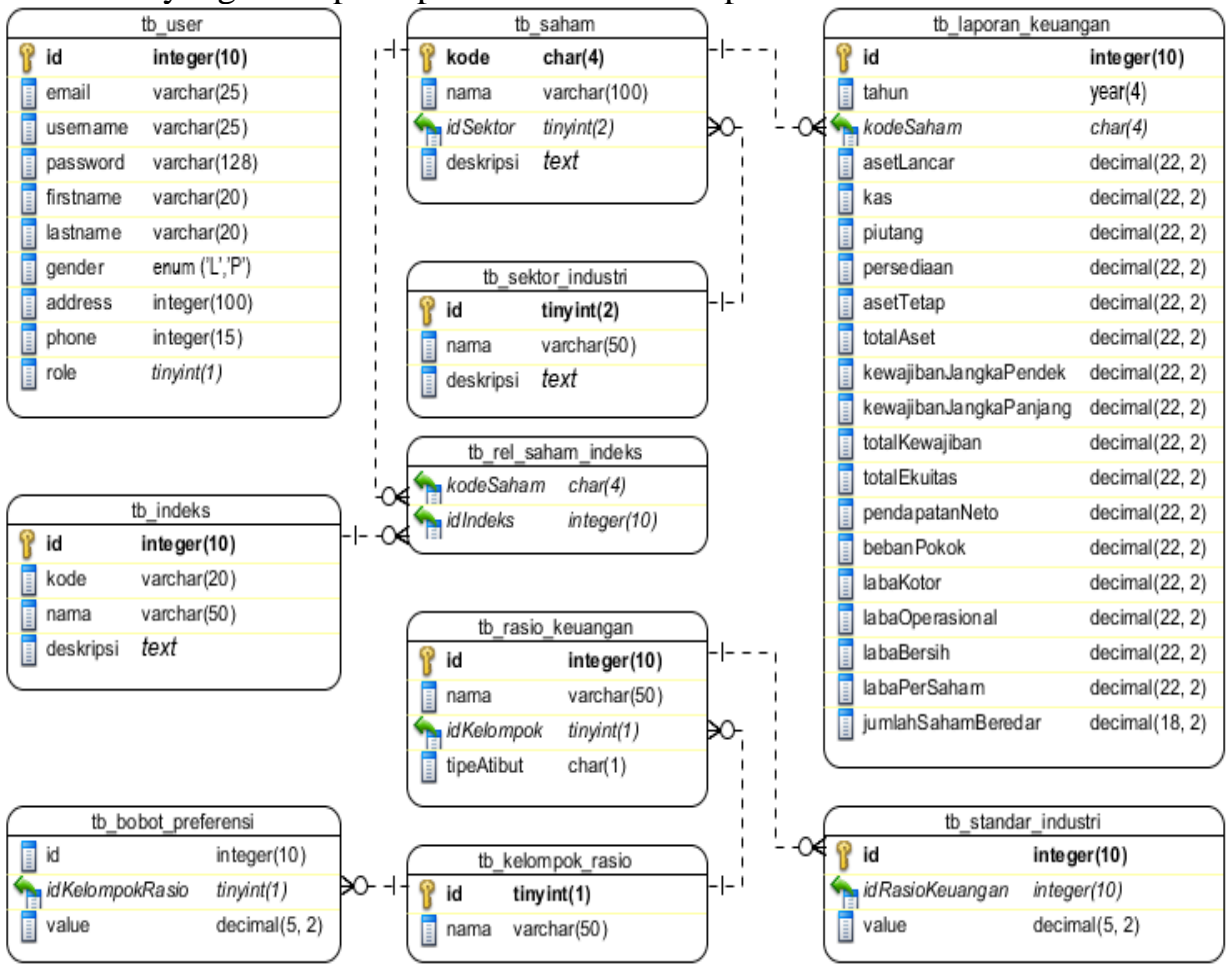

Gambar 5. Rancangan relasi antar tabel 


\section{Implementasi}

Implementasi merupakan tahapan untuk mengeksekusi serta menguji rancangan yang telah dibahas pada bab sebelumnya. Proses implementasi pada penelitian ini dilakukan pada sistem operasi Windows 10 Pro dengan menggunakan bahasa pemrograman PHP dengan bantuan Integrated Development Environment (IDE) PHPStorm 10 dan basis data MySQL.

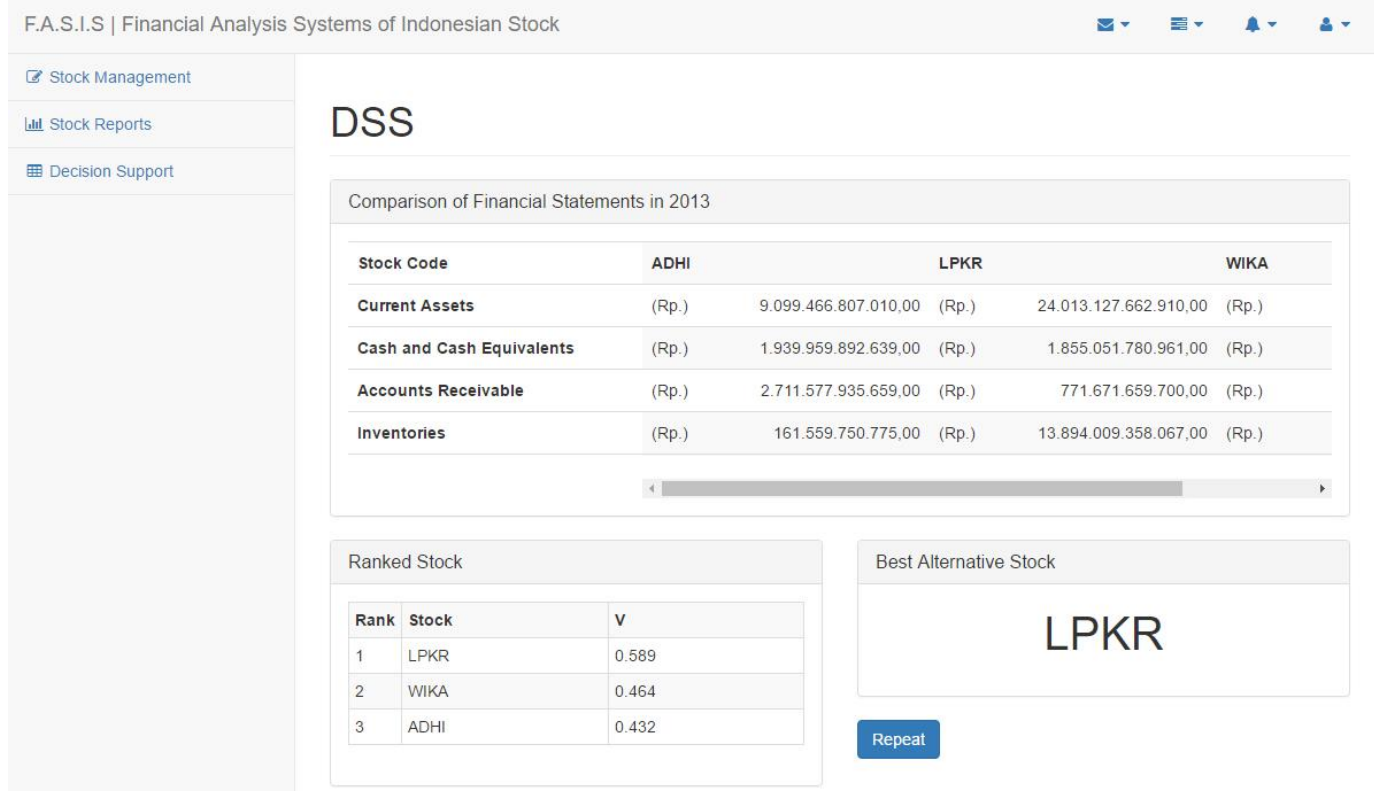

Gambar 6. Tampilan hasil dari proses sistem pemeringkatan

\section{Analisis Hasil}

1. Hasil Pengujian Data

Dari hasil pengujian data pada sistem pemeringkatan yang dikembangkan dan melibatkan data-data penelitian maka didapatkan hasil rekomendasi seperti Tabel 6 berikut:

Tabel 6. Hasil pengujian data pada sistem

\begin{tabular}{|c|l|c|c|c|}
\hline No & \multicolumn{1}{|c|}{ Sektor } & $\begin{array}{c}\text { Tahun } \\
\text { Laporan Keuangan }\end{array}$ & $\begin{array}{c}\text { Rekomendasi } \\
\text { Terbaik }\end{array}$ & $\begin{array}{c}\text { Nilai V } \\
\text { SAW-TOPSIS }\end{array}$ \\
\hline 1 & Barang Konsumsi & 2013 & SIDO & 0.673 \\
\hline 2 & Barang Konsumsi & 2014 & SIDO & 0.671 \\
\hline 3 & Barang Konsumsi & 2015 & KLBF & 0.679 \\
\hline 4 & Properti & 2013 & BSDE & 0.757 \\
\hline 5 & Properti & 2014 & BSDE & 0.713 \\
\hline 6 & Properti & 2015 & KIJA & 0.691 \\
\hline
\end{tabular}

Dalam penelitian ini terdapat perbedaan waktu yang cukup signifikan dalam proses analisis fundamental yang dilakukan secara manual (konvensional) dengan analisis fundamental yang dilakukan dengan bantuan sistem. Dimana analisis fundamental secara manual/konvensional membutuhkan waktu sekitar 1-2 jam untuk melakukan analisis fundamental satu laporan keuangan per satu periode, jadi untuk melakukan analisis fundamental saham terbaik dengan melibatkan 10 laporan keuangan dalam satu periode membutuhkan waktu 10-20 jam. Namun dengan bantuan sistem, analisis fundamental untuk mendapatkan rekomendasi terbaik dari 10 alternatif saham dapat dilakukan kurang dari 5 menit. 
2. Hasil Pengujian Akurasi

a. Skenario Pengujian 1

Pada skenario pengujian pertama ini akan menggunakan 50\% data training dan testing yang dipilih secara acak. Data diuji dengan aturan bahwa data emiten yang diuji harus dalam 1 sektor dan tahun laporan yang sama. Hasil akurasi dari skenario 1 terlihat pada Tabel 7 berikut:

Tabel 7. Hasil akurasi skenario 1

\begin{tabular}{|c|l|c|c|}
\hline No & \multicolumn{1}{|c|}{ Sektor } & Tahun & Akurasi \\
\hline 1 & Barang Konsumsi & 2013 & $100.00 \%$ \\
\hline 2 & Barang Konsumsi & 2014 & $100.00 \%$ \\
\hline 3 & Barang Konsumsi & 2015 & $90.00 \%$ \\
\hline 4 & Properti & 2013 & $90.00 \%$ \\
\hline 5 & Properti & 2014 & $90.00 \%$ \\
\hline 6 & Properti & 2015 & $90.00 \%$ \\
\hline
\end{tabular}

Dari tabel hasil akurasi pada skenario pertama ini maka didapatkan tingkat akurasi pada rentang $90 \%$ - 100\%. Detail perbandingan pada uji akurasi skenario 1 ini terlihat seperti pada grafik Gambar 7 berikut:

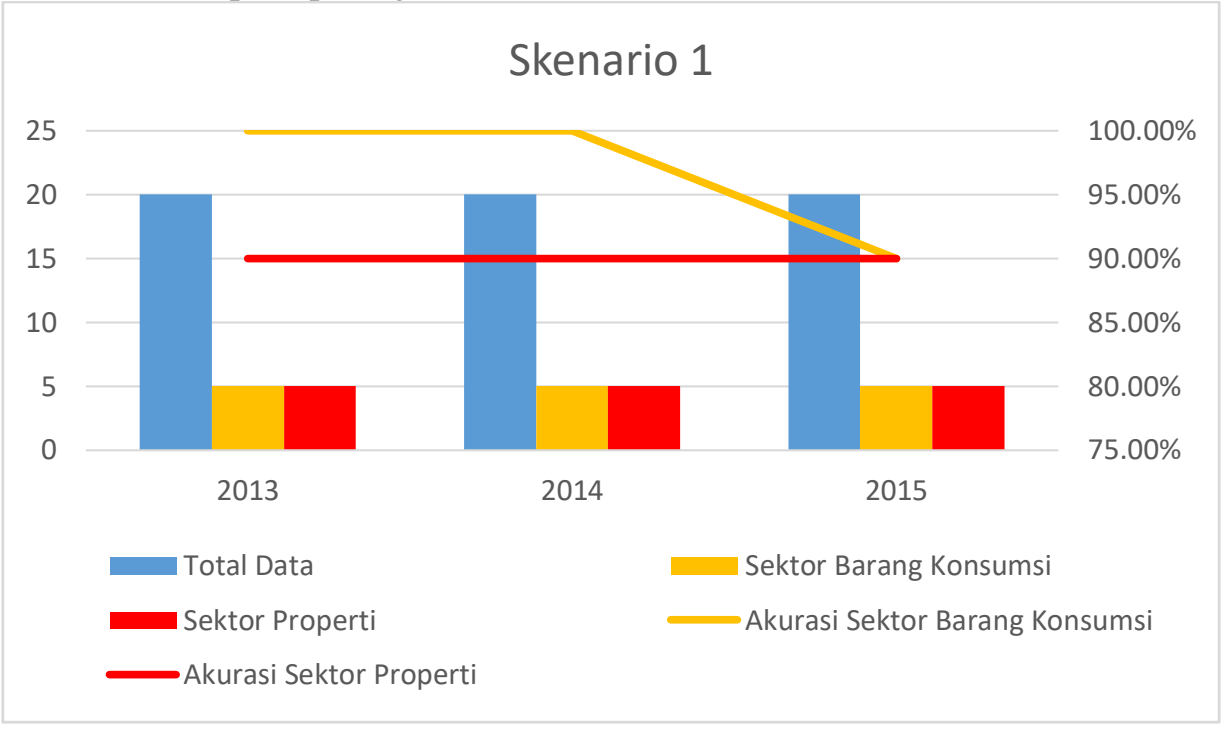

Gambar 7. Grafik pengujian akurasi skenario 1

b. Skenario Pengujian 2

Pada skenario pengujian kedua ini juga akan menggunakan 50\% data training dan testing yang dipilih secara acak. Namun pada skenario kedua ini data diuji dengan mencampurkan kedua sektor tapi masih dalam tahun laporan yang sama. Hasil akurasi dari skenario 2 terlihat pada Tabel 8 berikut:

Tabel 8. Hasil akurasi skenario 2

\begin{tabular}{|c|l|c|c|}
\hline No & \multicolumn{1}{|c|}{ Sektor } & Tahun & Akurasi \\
\hline 1 & Barang Konsumsi \& Properti & 2013 & $90.30 \%$ \\
\hline 2 & Barang Konsumsi \& Properti & 2014 & $92.73 \%$ \\
\hline 3 & Barang Konsumsi \& Properti & 2015 & $91.52 \%$ \\
\hline
\end{tabular}


Dari tabel hasil akurasi pada skenario kedua ini maka didapatkan tingkat akurasi tertinggi $92.73 \%$ dan terendah $90.30 \%$. Detail perbandingan pada uji akurasi skenario 2 ini terlihat seperti pada grafik Gambar 8 berikut:

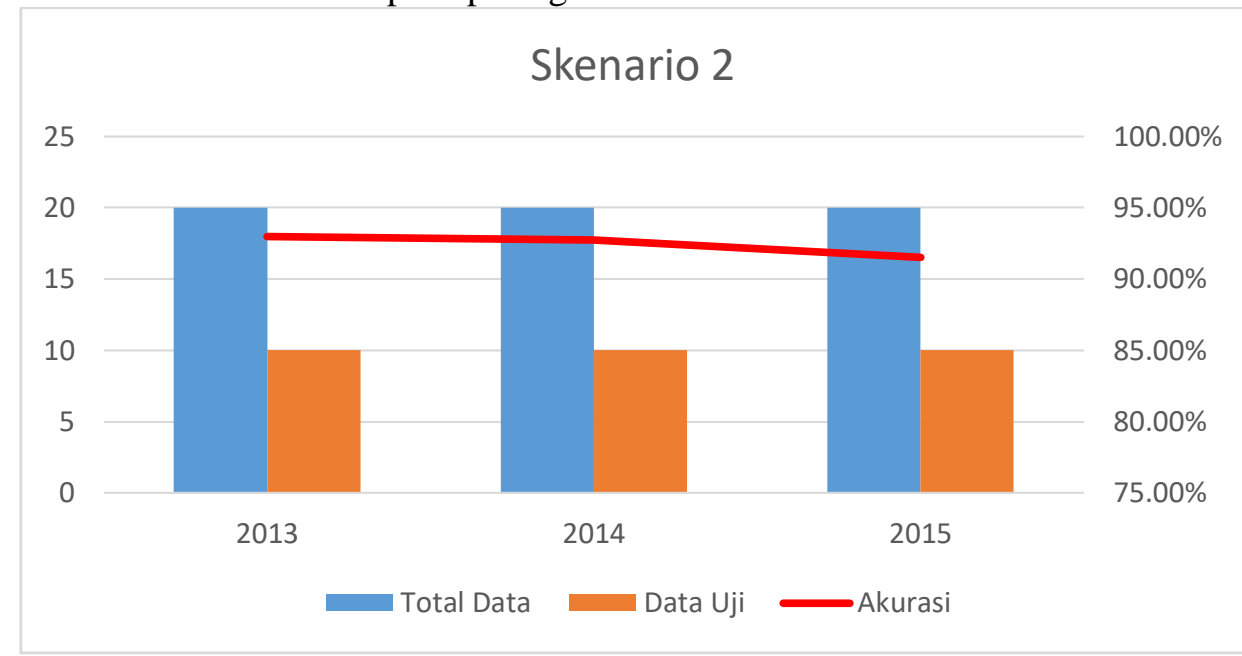

Gambar 8. Grafik pengujian akurasi skenario 2

c. Skenario Pengujian 3

Pada skenario pengujian ketiga ini data yang digunakan sama seperti skenario pengujian 2. Namun pada skenario ketiga ini data diuji dengan membandingkan hasil dari analisis fundamental metode SAW-TOPSIS pada tahun laporan $\mathrm{x}$ dengan metode Springate pada tahun laporan $\mathrm{x}+1$. Hasil akurasi dari skenario 23 terlihat pada Tabel 9 berikut:

Tabel 9. Hasil akurasi skenario 2

\begin{tabular}{|c|l|c|c|}
\hline No & Sektor & Tahun & Akurasi \\
\hline 1 & Barang Konsumsi \& Properti & $2013-2014$ & $93.94 \%$ \\
\hline 2 & Barang Konsumsi \& Properti & $2014-2015$ & $85.45 \%$ \\
\hline
\end{tabular}

Dari tabel hasil akurasi pada skenario ketiga ini maka didapatkan tingkat akurasi tertinggi $93.94 \%$ dan terendah $85.45 \%$. Detail perbandingan pada uji akurasi skenario 2 ini terlihat seperti pada grafik Gambar 9 berikut:

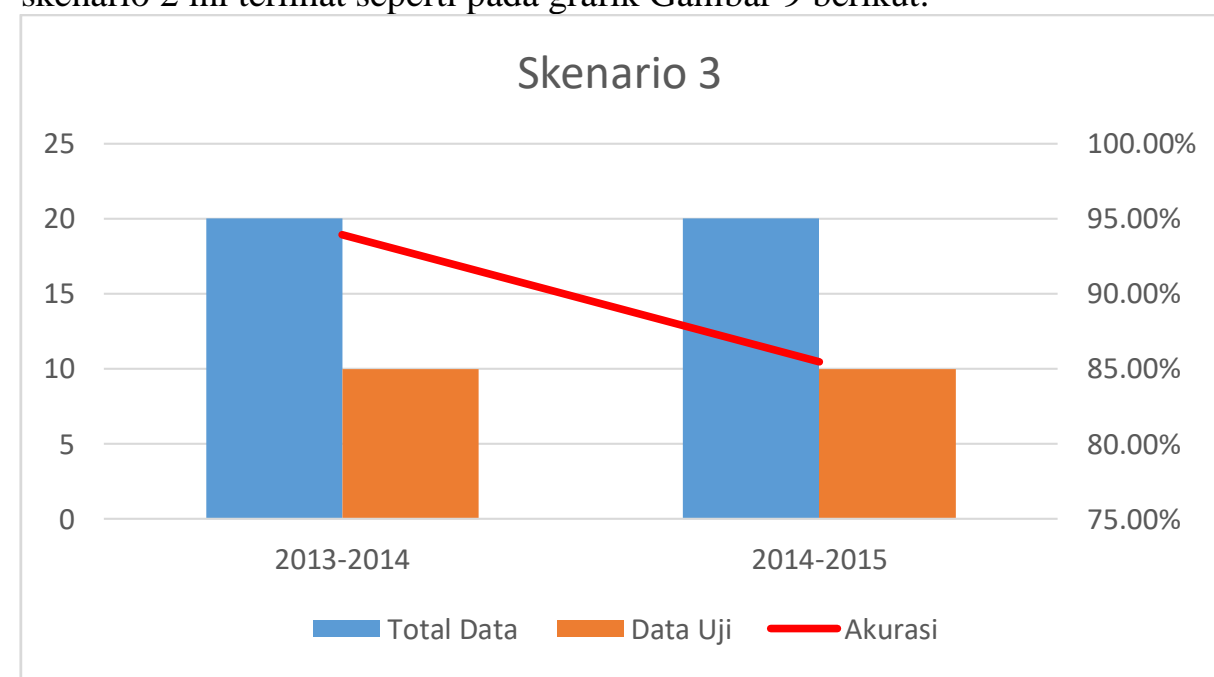

Gambar 9. Grafik pengujian akurasi skenario 3 
3. Kelebihan dan Kelemahan Sistem

Adapun kelebihan sistem yang dikembangkan dalam penelitian ini diantaranya:

a. Sistem yang dikembangkan berbasis web dan berjalan diatas platform PHP, sehingga dapat diakses dari manapun dan kapanpun selagi masih ada akses internet.

b. Sistem dapat menunjukkan hasil pemrosesan dalam bentuk pemeringkatan dan rekomendasi terbaik. Selain itu dapat dilihat juga tingkat akurasi dari hasil yang diproses.

Namun ada juga kelemahan pada sistem yang dikembangkan dalam penelitian ini diantaranya:

a. Jumlah data saham dalam sistem masih sangat terbatas dan data-data kunci laporan keuangan masih di-input-kan secara manual.

b. Bobot preferensi setiap kriteria masih bersifat statis berdasarkan aturan dari surat keputusan menteri BUMN.

c. Kualitas akurasi sangat tergantung dari bobot kriteria dan jumlah alternatif data.

4. Rekomendasi Implementasi Sistem

Untuk menunjang kinerja dalam penggunaan sistem pemeringkatan yang telah dikembangkan, direkomendasikan beberapa dalam implementasi sistem, diantaranya:

a. Sistem sebaiknya dijalankan pada Cloud Computer agar dapat dimonitor dan maintenance tanpa keterbatasan waktu dan tempat. Salah satu pihak penyedia Cloud Computer yang credible adalah Amazon Web Services, dan produk Amazon EC2 merupakan pilihan terbaik. Dimana informasi lebih lengkap dapat dilihat pada alamat https://aws.amazon.com/ec2/.

b. Adanya beberapa tingkatan pengguna dalam sistem, diantaranya:

i. Root, merupakan pengguna yang mempunyai hak akses paling tinggi. Dalam kata lain root adalah pemilik resmi dari sistem.

ii. Admin, merupakan pengguna yang diberi wewenang oleh root untuk mengelola sistem, syarat utama untuk dapat menjadi admin adalah harus memahami ilmu analisis fundamental berdasarkan rasio keuangan, mampu membaca laporan keuangan, dan mampu mengelola data yang ada dalam laporan keuangan ke dalam sistem.

iii. Member/End User, merupakan pengguna akhir dari sistem yang akan dilayani oleh sistem. Member/End User bisa merupakan seorang investor berpengalaman maupun orang awam yang ingin memulai berinvestasi.

c. Sistem sebaiknya dapat mengarahkan/memberi panduan penggunaan sistem saat ada member yang baru meregisterkan diri. Sehingga baik member yang sudah berpengalaman dalam bidang investasi saham maupun yang baru mulai belajar dapat dengan mudah menjalankan fitur-fitur yang ada pada sistem.

\section{Kesimpulan}

Berdasarkan penelitian yang sudah dilakukan dapat ditarik beberapa kesimpulan:

1. Penelitian Penerapan Kombinasi Metode SAW Dan TOPSIS Dalam Analisis Fundamental Saham Berdasarkan Rasio Keuangan dapat dilakukan dengan cara menghitung nilai rasio keuangan sebagai kriteria, memberi bobot masing-masing kriteria, menormalisasikan nilai hasil rasio keuangan ke dalam bentuk bilangan fuzzy berdasarkan standar rasio keuangan, membentuk matriks keputusan, menormalisasikan matriks keputusan berdasarkan metode SAW, membuat matriks ternormalisasi terbobot, menentukan matriks solusi ideal positif dan negative, menentukan jarak antara nilai setiap alternatif, dan menghitung nilai preferensi setiap alternatif (Vi) untuk dibandingkan. 
2. Berdasarkan pengujian akurasi metode SAW-TOPSIS menggunakan uji koefisien korelasi pemeringkatan Spearman berdasarkan model Springate pada skenario 1 didapatkan tingkat akurasi pemeringkatan tertinggi yakni sebesar $100 \%$ dan terendah 90\%. Dan pada pengujian skenario 2 didapatkan tingkat akurasi pemeringkatan tertinggi yakni sebesar $92.73 \%$ dan terendah $90.30 \%$. Dan pada pengujian skenario 2 didapatkan tingkat akurasi pemeringkatan tertinggi yakni sebesar 93.94\% dan terendah $85.45 \%$. Dari hasil uji akurasi tersebut metode SAW-TOPSIS dapat diterapkan pada analisis fundamental saham berdasarkan rasio keuangan.

3. Tingkat hasil akurasi pada penelitian ini dapat berubah-ubah mengikuti nilai bobot preferensi yang diberikan pada setiap kriteria dan juga jumlah alternatif data yang diuji.

4. Sistem yang dikembangkan dalam penelitian ini dapat mengakomodasi pemeringkatan alternatif saham dan memberikan hasil rekomendasi terbaik untuk berinvestasi dengan waktu yang lebih singkat.

\section{Saran}

Berdasarkan dari penelitian yang sudah disimpulkan maka dalam upaya pengembangan dikemukakan beberapa saran sebagai berikut :

1. Sistem Pemeringkatan Saham pada penelitian ini data saham masih terbatas dan data kunci laporan keuangan yang dibutuhkan untuk analisis fundamental berdasarkan rasio keuangan masih di-input-kan secara manual, diharapkan pada pengembangan penelitian selanjutnya data dapat diambil menggunakan web service dari Bursa Efek Indonesia untuk proses yang lebih efisien.

2. Metode untuk pendukung keputusan dapat dikembangkan lagi dengan metode lain yang dapat mengakomodasi pembobotan kriteria secara dinamis berdasarkan profil resiko investasi seperti metode ANP ataupun AHP.

\section{Daftar Pustaka}

\section{Pustaka Buku}

Arifin, Johar., 2007, Cara Cerdas Menilai Kinerja Perusahaan Berbasis Komputer, Elex Media Komputindo, Jakarta.

Fakhruddin, Hendy M., 2008, Istilah Pasar Modal A-Z, Elex Media Komputindo, Jakarta.

Hery., 2015, Analisis Laporan Keuangan Pendekatan Rasio Keuangan, CAPS, Yogyakarta.

Irwansyah, Edy, dan Muhammad Faisal., 2015, Advanced Clustering: Teori dan Aplikasi, Deepublish, Yogyakarta.

Kusrini., 2007, Konsep dan Aplikasi Sistem Pendukung Keputusan, Andi Publisher, Yogyakarta.

Kusumadewi, Sri, et al., 2006, Fuzzy Multi-Attribute Decision Making (Fuzzy MADM), Graha Ilmu, Yogyakarta.

Kuswadi., 2006, Memahami Rasio-Rasio Keuangan bagi Orang Awam, Elex Media Komputindo, Jakarta.

Maturidi, Ade Djohar., 2012, Metode Penelitian Teknik Informatika, Deepublish, Yogyakarta.

Nofriansyah, Dicky., 2014, Konsep Data Mining vs Sistem Pendukung Keputusan, Deepublish, Yogyakarta. 
Siagian, Dergibson, dan Sugiarto., 2006, Metode Statistika Untuk Bisnis dan Ekonomi, Gramedia Pustaka Utama, Jakarta.

Wahyudiono, Bambang., 2014, Mudah Membaca Laporan Keuangan, Raih Asa Sukses, Jakarta.

\section{Pustaka Majalah, Jurnal Ilmiah atau Prosiding}

Falani, Achmad Zakki., 2013, Analisis Laporan Keuangan Perusahaan Sebagai Dasar Pengambilan Keputusan Investasi Saham Berbasis Du Pont System \& Fuzzy Logic, Jurnal LINK Vol 18/No.1/Maret 2013, ISSN: 1858-4667.

S, Henry Wibowo, 2010, MADM-Tool:Aplikasi Uji Sensitivitas untuk Model MADM Menggunakan Metode SAW dan TOPSIS, Seminar Nasional Aplikasi Teknologi Informasi 2010, ISSN: 1907-5022

Setyawan, Yan Satria, et all., 2013, Implementasi Metode Fuzzy Analytical Hierarchy Process (F-AHP) Sebagai Pendukung Keputusan Investasi Pada Perusahaan Berdasarkan Rasio Keuangan (Studi Pada Perusahaan Farmasi Yang Terdaftar di BEI Periode 2013), Jurnal PTIIK Universitas Brawijaya, vol. 5, no. 10.

Wang, Tien-Chin, et al., 2010, Applying TOPSIS method to evaluate the Business Operation Performance of Vietnam Listing Securities Companies, International Conference on Computational Aspects of Social Networks,ISBN:978-1-4244-8785-1.

Zorro, Carlos Cubaque.; Garcia, Figueroa., 2014, A Fuzzy Logic System For Evaluating Financial Profit Ratios, IEEE Conference on Norbert Wiener in the 21st Century (21CW), ISBN: 978-1-4799-4562-7.

\section{Pustaka Laporan Penelitian}

B, Muslimin., 2016, Sistem Pendukung Keputusan Kelompok Dalam Pemilihan Saham Menggunakan Metode AHP,Promethee dan Borda, Tesis, S2 Ilmu Komputer Universitas Gadjah Mada, Yogyakarta.

Laymond S, Rajim., 2013, Sistem Pendukung Keputusan Pemilihan Saham Berbasis Web Dengan Pemodelan AHP (Analytic Hierarchy Process) Dan Analisis Rasio Keuangan, Tesis, S2 Ilmu Komputer Universitas Gadjah Mada, Yogyakarta.

\section{Pustaka Elektronik}

BUMN, Kementerian, 13 Oktober 2016, INDIKATOR PENILAIAN TINGKAT KESEHATAN BADAN USAHA MILIK NEGARA JASA KEUANGAN BIDANG USAHA PERASURANSIAN DAN JASA PENJAMINAN, Jakarta, http://bumn.go.id/data/uploads/files/1/PER-10-MBU-2014.PDF

Indonesia, Bursa Efek., 07 September 2016, Daftar Efek Saham, Jakarta, http://www.idx.co.id/id-id/beranda/informasipasar/daftarefek/saham.aspx

Keuangan, Otoritas Jasa, 3 November 2016, UNDANG-UNDANG REPUBLIK INDONESIA NOMOR 8 TAHUN 1995 TENTANG PASAR MODAL, Jakarta, http://www.ojk.go.id/id/kanal/pasar-modal/regulasi/undangundang/Documents/313.pdf

Mulyanto, Prihatmo Hari., 07 Oktober 2016, Menakar Sektor Prospektif 2016, Jakarta, http://koran.bisnis.com/read/20160411/251/536617/menakar-sektor-prospektif-2016 